\title{
Autoimmunity and Apoptosis - Therapeutic Implications
}

\author{
Iran Rashedi ${ }^{1,4}$, Soumya Panigrahi ${ }^{2,4}$, Peyman Ezzati ${ }^{1,4}$, Saeid Ghavami ${ }^{1,4}$ and Marek Los ${ }^{*, 1,3,45}$ \\ ${ }^{1}$ Department of Biochemistry and Medical Genetics, ${ }^{2}$ Department of Physiology, ${ }^{3}$ Department of Human Anatomy and Cell Science, \\ Faculty of Medicine, ${ }^{4}$ CancerCare Manitoba, University of Manitoba, ${ }^{5}$ BioApplications Enterprises, Winnipeg, Canada
}

\begin{abstract}
Acquisition of a complex immune system during evolution provided organisms with the most effective defense mechanism against "foreign" or "non-self" invaders. This efficient protection against pathogens, however, has been achieved at the expense of a higher risk for "self"-directed reaction or autoimmunity. Establishment of self-tolerance and homeostasis in the immune system is regulated at different physiological stages of immune cells development. The breakdown in discrimination between "self" and "non-self" causes an aberrant immune response against autoantigens that promote damage to the "self" cells and tissue(s), resulting in various autoimmune phenotypes. Whereas activation and clonal proliferation of autoreactive T- and B- lymphocytes underlies the pathogenesis of autoimmune diseases, the mechanism by which self-tolerance is lost and autoimmune responses are induced is not clear yet. Autoimmunity is a multi-step process that occurs as a consequence of complex interaction between genetic susceptibility and non-genetic factors. Programmed cell death, as a key mechanism to regulate immune system function, has a crucial influence on both the selection process of immune cells and the maintenance of this immune tolerance in peripheral repertoire. Thus, defects in apoptotic death pathways may contribute to the development of autoimmune response in susceptible individuals in certain conditions.
\end{abstract}

Keywords: Autoimmunity, apoptosis, autoantigen, autoantibody, adaptive immune response, innate immune system, tolerance.

\section{INTRODUCTION}

The physiological role of the immune system is to defend against foreign, invading pathogens, which needs to be distinguished from normal self-antigens. Acquiring tolerance to selfconstituents is a complex and multi-step process and loss of this tolerance may lead to inappropriate activation of immune system, causing tissue damage and autoimmune diseases. Despite the heterogeneity in clinical and molecular characteristics, the common feature of autoimmune conditions is the presence of autoreactive lymphocytes that target "self"-molecules and destroy them. The factors and the mechanisms by which they contribute to the development of autoimmunity are not completely understood, yet the combination of genetic defects in regulatory mechanisms of immune system as well as non-genetic factors appear to play roles in predisposing to autoimmune diseases. The association between the alleles of major histocompatibility complex (MHC) and susceptibility to autoimmune diseases has been known for several years, though more recently it has been proposed that a number of other loci and biochemical pathways are involved in the pathogenesis of these disorders [1-9]. Many of these studies discuss the role of programmed cell death signaling in initiating and perpetuating the autoimmune process indicating the biological importance of apoptosis in modulating immune responses and T- and B-cell development $[10,11]$. Apoptosis signaling cascades are believed to play a role in maturation of the immune system and its further homeostasis, thus being key to the regulation of both acquisition and maintenance of self-tolerance. Defects in apoptosis pathways contribute to a destructive immune response to autoantigens in many ways, including either ineffective deletion of autoreactive lymphocytes during negative selection process, creating new immunogenic selfpeptides or insufficient clearance of autoparticle-containing phagocytic cells during an immune response.

Here, we illustrate the components of an immune response and the mechanisms that lead to autoimmunity. Then, we discuss the role of programmed cell death in normal immune system maturation and the various ways it may contribute to autoimmune process and finally, current biotherapy concepts and challenges that clinical sciences face when attempting to treat autoimmune disorders.

*Address correspondence to this author at the BioApplications Enterprises, 34 Vanier Dr., Winnipeg, MB, R2V 2N6, Canada; Tel: +1-(204) 334 5192; Fax: +1-(204) 7872190; E-mail: bioappl@gmail.com

\section{IMMUNE SYSTEM PHYSIOLOGY AND AUTOIMMUNE RESPONSES}

The result of evolutionary changes in host defense mechanisms has been the development of a complex adaptive immune system in mammals to protect them against a vast variety of pathogens such as viruses, bacteria, fungi, and parasites. Efficient and flexible immune response requires the ability to recognize sometimes minimal differences between "self" and foreign material. Any failure in this discrimination along with inappropriate under- or over-activation of the immune system can result in pathological conditions such as immune deficiency or autoimmune disorders. In autoimmunity the failure of an immune response that is directed against various selfcomponents to completely eliminate self antigens results in a persistent autoreactive response, which consequently causes damage to the tissue against whose antigens the immune reaction has been formed.

Autoimmune responses, in effect, are a consequence of the natural ability of $\mathrm{B}$ - and $\mathrm{T}$-cell receptors to recognize and react to any antigenic product. This implies that transient autoimmune responses are not uncommon in physiological states; however, it is the persistent reaction against autoantigens that causes tissue damage and results in autoimmune pathologies. In humans, discrimination between "self" and "non-self", and the following tolerance to autologous antigens are mainly acquired in central lymphoid organs, though there is broad agreement on the analogous role of secondary lymphoid tissues in the establishment of immune tolerance [12-14]. The acquisition of this tolerance in the central lymphoid compartment (bone marrow and thymus) is achieved during lymphocyte development (central tolerance) by specific deletion of those clones of immature lymphocytes that express receptors which bind to ubiquitous self-antigens with high affinity (clonal deletion) [15].

These lymphocytes with high binding affinity to autoantigens experience a death signal and undergo apoptosis during a process called negative selection. Nevertheless, under physiological conditions, not all the self-peptides are presented to T-lymphocytes in the thymus [16], and consequently autoreactive lymphocytes that escape clonal deletion can be found in the periphery. These potentially self-reactive cells are kept under control by diverse mechanisms responsible for maintaining self-tolerance in periphery (peripheral tolerance). These include deletion or inactivation of mature peripheral T- and B-cells (anergy) due to not receiving costimulatory signals, ignorance of autoantigens, activation-induced cell death of autoreactive T-cells (AICD), as well as the toleranceinducing effect of regulatory $\mathrm{T}$-lymphocytes $\left(\mathrm{T}_{\text {regs }}\right)$ and dendritic cells (DCs) [15]. T-cells that are unable to produce IL-2 upon en- 
countering the antigen cannot be completely activated and are called anergic $[17,18]$. Some of these anergic T-cells produce IL10 , which suppresses the activation of T-cells [19]. Reduction in the number of these anergic cells in the peripheral repertoire confers the susceptibility to autoimmune disorders [16].

Ignorance of self-antigens occurs either when these molecules are expressed at too low levels to induce the activation or deletion of T-cells $[20,21]$ or when they are present in immune privileged sites, physically separated from T-lymphocytes (i.e. lens, some compartments within the testis) [22, 23]. As long as these regulatory mechanisms work efficiently, self-reactive T-cells do not cause any disease. However, this self-tolerance is bypassed in some cases leading to autoimmune diseases. One reason for this is the variation in deletion of self-reactive T-lymphocytes in the thymus. For instance, one of the genes conferring susceptibility to autoimmune diabetes is responsible for determining the intrathymic level of insulin $[13,24]$. The process of clonal deletion of autoreactive lymphocytes influences the type of subsequent autoimmune disease. The autoantigens that do not induce clonal deletion in the thymus, either because of their scarcity or tissue-specific fashion of expression, later develop autoimmune pathologies in the restricted target organs in susceptible individuals.

More systemic demonstration of autoimmunity occurs when inherited defects in the regulatory mechanisms of immune responses or the impaired clearance of dying cells provokes the tolerance to self-proteins that are ubiquitously available in the body. The antigen or group of antigens against which the autoimmune responses are mounted and the mechanism by which the antigen-bearing tissue is damaged also determine the pathogenesis and clinical presentations of autoimmune diseases. A variety of potential triggers have been described to induce these aberrant immune responses, including foreign antigens of viruses or bacteria, release of sequestered antigenic peptides, altered self-antigens, increased expression of MHC glycoproteins that present autoantigens, polyclonal B-cell activators, molecular mimicry of immunogenic particles, and chronic inflammation [25]. Whatever the mechanism of initiation, targeting of autologous peptides and the consequent tissue damage can be mediated by both effector T- and B-cells in genetically predisposed individuals. Similar to a physiological adaptive immune response in which foreign particle peptides are presented in association with MHC molecules at the surface of phagocytic cells to a $\mathrm{CD} 4^{+}$T-lymphocyte, autoimmunity is assumed to initiate by the activation of antigen-specific T-cells. Autoantigen-directed activation of T-cells can damage target tissues either directly by the action of cytotoxic T-cells $\left(\mathrm{CTLs} / \mathrm{CD}^{+}\right)$, or indirectly through inappropriate activation of macrophages by the $\mathrm{T}_{\mathrm{h}} 1$ - (known also as Thelper 1) subclass of $\mathrm{CD} 4^{+} \mathrm{T}$-cells or production of autoantibody by B-cells which become activated by $\mathrm{T}_{\mathrm{h}} 2$-cells. While in some autoimmune diseases a receptor-targeting antibody is the major effector, in some others immune complexes are responsible for the tissue damage. In organ-specific conditions, $\mathrm{CD}^{+}$and/or $\mathrm{CD}^{+} \mathrm{T}$-cells are mostly implicated in destructive immune response; however, Tcells are crucially important for both humoral and cell-mediated adaptive immune responses, and in a similar way, in originating autoimmune responses. In antibody-mediated autoimmunity, IgG or IgM recognize and react to autoantigens located on cell surfaces or the extracellular matrix, leading to rapid destruction of these cells. Autoantibodies can also respond to soluble self-antigens, causing a more generalized and systemic tissue damage.

After neutralization of foreign antigens, a normal immune response terminates as an effect of several regulatory mechanisms. These include the expression of downregulatory signals such as cytokine transforming growth factor beta (TGF- $\beta$ ) and cytotoxic Tlymphocyte antigen 4 (CTLA4/CD152) by activated T-cells. The latter generates a negative signal to the T-cells upon binding to CD80/B7-1 and CD86/B7-2 on an antigen presenting cell (APC), inhibiting further activation of T-cells [26]. These suppressive mechanisms serve to a punctual shut down of the immune response after successful removal of the foreign antigen. In autoimmunity, however, since the autoantigen cannot be eliminated, the effector Tand B-cells are constantly recruited and activated, and the immune response will not end.

In addition to the role of the adaptive immune system and its multiple players in the pathogenesis of autoimmunity, which has been vastly investigated during past few decades, involvement of innate immune responses in the development of autoimmune reactions has also gained attention in more recent studies [27-29]. The innate immune system is an ancient mechanism of defense against common threats of microorganisms, in which several families of receptors have evolved to recognize the molecular patterns found in these invaders. However, these pattern-recognition receptors including toll-like receptors (TLRs) and NOD-like receptors can mediate an aberrant immune response to the components of "self" leading to several autoimmune conditions [30].

\section{CONTRIBUTORS TO AUTOIMMUNITY}

Although tolerance to autologous molecules is the general rule in a healthy immune system, persistent immune response to "self"components occurs in some cases. The fact that autoreactive B- and T-cells are parts of normal person's immune system but progression to destructive autoimmunity is only seen in some individuals suggests that specific predisposing factors exist which contribute to the initiation and perpetuation of autoimmune processes in certain conditions. The multifactorial nature of autoimmune disorders makes it difficult to identify various contributors to the disease. There is a general persuasion, however, that loss of tolerance and occurrence of autoimmunity happens as an interaction between genetic and environmental influences. This is partly due to the complex nature of the immune response, which involves multiple genes and regulatory elements on one side and multiple "recent" and "far" environmental exposures that may act as either negative or positive effectors. Adding to this complexity, environmental interference may be nonspecific simply resulting in tissue damage and release of autoantigen, or it may specifically affect genetically susceptible individuals.

\section{GENETIC BASIS OF AUTOIMMUNITY}

Results of family studies evidence the importance of both inherited and environmental factors in induction of autoimmunity. Studies with twins have indicated a higher concordance of autoimmune disorders in monozygotic twins compared to dizygotic twins [3133]. In addition to these findings in humans, certain inbred murine strains show a consistent susceptibility to particular spontaneous or experimentally induced autoimmune diseases [34, 35]. Through extensive attempt to uncover the susceptibility loci, the association of MHC alleles (known as human leukocyte antigen/HLA region in human) with autoimmune diseases was identified many years ago. For most of autoimmune disorders, susceptibility is strongly linked with MHC class II alleles, but associations with particular alleles of MHC class I is also seen in some cases [36-38]. The contribution of MHC genotype to autoimmune phenotype refers to the nature of the immune response, which is defined by the ability of T-cells to recognize an antigen presented in association with MHC molecules. How exactly MHC confers the risk is not certain, but there is a presumption that the antigen binding groove of these class II MHC molecules has a high affinity to bind autoantigenic peptides. It is likely that during the selection of immuno-competent cells, binding characteristics of these MHC molecules to self-antigenic peptides are too poor to drive negative selection, but strong enough to induce their positive selection. MHC molecules have a strict specificity for the peptide antigens they present. This selectivity of distinct $M H C$ allelic variants to process and present autoantigens to T-cells may 
be partly responsible for the variable susceptibility to autoimmunity. Yet, not all individuals harboring risk-associated $H L A$ alleles in population show the autoimmune phenotype. In fact, there are even several $H L A$ alleles that show a protective effect for the induction of certain autoimmune diseases. $H L A-D R B 1 * 1501$ is one of these alleles which is negatively associated with development of IDDM. This is postulated to be an effect of improved binding of islet autoantigens including proinsulin peptides to DR2 molecules on thymic APCs, followed by higher-affinity interaction with Tlymphocytes, which leads to a more effective deletion of these selfreactive T-cells in thymus [39]. Additionally, there are genes identified in murine model of SLE that confer resistance to the disease [40]. These findings suggest that $M H C$ allelic variation could not be the only genetic predisposing factor for the loss of tolerance and autoimmunity. The fact that monozygotic twins are more likely to develop the same autoimmune disorder than $M H C$-identical siblings suggests that a number of different loci are involved in autoimmune susceptibility. Many of these genetic variants are engaged in the Tcell signaling cascade mediated by T-cell receptor (TCR/CD3), but there are also some loci whose association seems to be restricted to a specific disorder or certain ethnic groups $[3,6,41]$.

Each of the many steps from induction to termination and memory state of an immune response could be involved in the development of an aberrant immune response. Common autoimmune conditions might be considered as a consequence of abnormal behavior of different cellular compartments including target tissue, antigen-presenting cells (APCs), and lymphocytes as major players of adaptive immune response. In target tissues the ubiquitously expressed antigens may undergo distinct conformations under the influence of the tissue-specific microenvironment, which may increase the immunogenicity of these autopeptides, resulting in initiating autoimmune responses under certain circumstances. These conformational changes including splicing alterations, posttranslational modifications, folding, and oligomerization affect structural and functional properties, expression profile, and subcellular localization of the "self"-peptides, many of which are cellular receptors and enzymes leading to the generation of an autoimmune response [9, 42-44]. Autoimmunity may also originate from the function of APCs in processing and presenting antigenic molecules to T-helper cells. The most studied molecular basis for the involvement of APCs in autoimmune phatogenesis is the combinatory variation of $\mathrm{MHC}$ alleles, which determines the affinity of cell surface receptors binding to peptide antigens that are associated with autoimmune process.

In addition to effects of tissue and APC properties, variations in $\mathrm{T}$-cell development with regard to defective thymic apoptosis of Tcells carrying autoreactive T-cell receptors (TCRs) and/or lack of sufficient $\mathrm{T}_{\text {regs }}\left(\mathrm{CD}^{+}, \mathrm{CD} 25^{+}\right)$, which are responsible for the development of peripheral immune tolerance, serve as other potential mechanisms contributing to autoimmunity. Lack of costimulatory molecules and those which amend TCR signaling might also have a key role in establishing autoimmunity. Autotolerance modulatory effect of $\mathrm{T}_{\text {regs }}$ is contact-dependent and is mediated by TGF- $\beta$ and CTLA4 immunoreceptors that have a regulatory role on T-cell proliferation [45-47]. Thus, T-cells expressing variant alleles of the genes that are associated with autoimmune conditions (e.g. CTLA4 and the protein tyrosine phosphatase 22 gene (PTPN22)) could serve as sources of autoreactivity. In CTLA4, genetic alterations in a $3^{\prime}$ untranslated region (3'UTR) as well as a single nucleotide polymorphism (SNP) which encodes the substitution of a threonine to alanine was found to associate with autoimmune thyroid diseases and several other disorders such as insulin-dependent diabetus mellitus (IDDM), systemic lupus erythematosus (SLE), Addison's disease, multiple sclerosis (MS) and rheumatoid arthritis (RA) [5, 4851]. The 3'UTR variant is also known to be associated with a reduced number of circulating $T_{\text {regs }}$, indicating a controlling effect of this allele on development and lineage commitment of T-cells [46].
PTPN22 encodes lymphoid tyrosine phosphatase (LYP) which modulates the activity of Lck and other kinases involved in early events of signaling cascade mediated through TCR [52]. A variant of PTPN22 that encodes a tryptophan as a substitute for arginine at codon $620(620 \mathrm{~W})$ has been shown to increase the risk of IDDM, RA, SLE, and Grave's disease (GD), but not those of psoriasis, MS and Crohn's disease [1, 2]. The disease-associated 620W allele seems to inhibit TCR activation, though the exact mechanism by which it acts is uncertain.

Recent studies have nominated several other genes as susceptibility loci for both common and tissue-restricted autoimmune diseases. Polymorphisms in peptidylarginine deaminase $(P A D I)$ and insulin genes (INS) are associated with RA and IDDM respectively $[53,54]$ whereas variants of $P D C D 1$ (encoding programmed cell death 1), SLC22A4 (within cytokine gene cluster), FCRL3 (encoding receptors with homology to the Fc-receptors of Ig), SUMO4 (small ubiquitin-like modifier 4), and CD25 (encoding a subunit of the IL-2 receptor complex) have been shown to be associated with several autoimmune conditions including SLE, RA, IDDM, Crohn's disease and autoimmune thyroid disorders [3, 4, 6, 7, 41, $55,56]$. Also, genetic lesions including point mutations in AIRE as well as complement deficiency have been vastly shown to be associated with an increased chance of autoimmunity [57-66]. This list is still being updated by an abundance of information that emerges from genotype susceptibility studies using animal models, genomewide mapping, and array technologies that investigate the gene expression profile during a particular immune response.

\section{APOPTOSIS}

The apoptotic process is a complex, precisely tuned series of events that plays a crucial role during the life cycle of an organism. It is responsible for eliminating unwanted cells during organ development, tissue remodeling, and homeostasis. When initiated, apoptosis follows a series of events that ultimately result in a destruction of the cell. The process is distinct from other types of cell death, like autophagia or necrosis. Apoptotic cells go through an orderly sequence of biochemical and morphological changes including activation/deactivation of cellular enzymatic pathways and rearrangement of subcellular and plasma membrane constituents [11, 67]. These changes confer typical apoptotic phenotypes including chromatin condensation and DNA fragmentation, cytoplasmic shrinkage, membrane blebbing, and formation of apoptotic bodies. Apoptotic bodies are membrane-bound vesicles containing reorganized subcellular components being degraded. After formation, apoptotic bodies are rapidly ingested by surrounding phagocytes via a receptor-mediated mechanism which efficiently prevents the constituents of dying cell/s to be released and exposed to extracellular matrix [68]. This uptake, in association with a suppression of the inflammatory response due to enhanced secretion of anti-inflammatory cytokines (e.g., TGF- $\beta$, IL-10) and failure to upregulate costimulatory molecules preclude the development of autoreactive response which is important for maintaining the self-tolerance [69-71].

Apoptosis is regulated by two classes of pro- and antiapoptotic proteins whose intricate interactions and relative abundance determine cell fate between survival and death. In mammalian cells, apoptosis can be triggered through either intrinsic (also known as stress-mediated) or extrinsic (receptor-mediated) pathways [11, 72]. The latter proceeds through the recruitment of death receptor family members (such as Fas/CD95, TRAILR1, TRAILR2, and TNF-R1) which share a homologous intracellular region called the death domain (DD) whose integrity is required to mediate apoptotic signal $[73,74]$. Trimerization and activation of death receptors occur through their interaction with several related TNF family ligands which are normally expressed by CTLs. Subsequent events include the formation of a DD-dependent molecular complex called DISC which triggers activation of initiator caspases such as caspase-8. 
The intrinsic/mitochondrion-mediated pathway of apoptosis is induced by a variety of death insults including DNA damage, metabolic imbalance, as well as loss of cell survival signals [75-79]. Cell death, mediated by this pathway, is associated with the release of cytochrome $\mathrm{c}$ and is mainly regulated by the Bcl-2 family of proteins. The homodimerization of proapoptotic members of $\mathrm{Bcl}-2$ family including Bax, Bak, Bim, Bik and Bid results in alteration of mitochondrial membrane permeabilization, which in turn allows the release of proteins such as cytochrome c, Omi/HtrA2, and Smac/DIABLO from mitochondrial intermembrane space into the cytosol. Once released, cytochrome c binds to Apaf-1, which together with dATP and procaspase- 9 forms a dynamic apoptosome complex at which procaspase- 9 becomes oligomerized and activated to form caspase- 9 . Active caspase- 9 subsequently activates downstream caspase-3 as an effector protease to promote cell death $[80,81]$. Caspases are a family of proteins which are synthesized as proenzymes and are activated by proteolytic processing (usually by autophosphorylation) that removes their N-terminal part. Whereas some caspases are cleaved and activated by other family members, activity of upstream/initiator caspases is controlled by adaptor proteins [82]. Apaf-1 and FADD are examples of these adaptor molecules that bind to and regulate activities of caspase- 9 and caspase- 8 respectively. The activities of adaptor proteins are in turn modulated by a number of regulatory proteins. For instance, the antiapoptotic members of the Bcl-2 family inhibit the activation of caspase9 in an apoptosome complex, and c-FLIP interferes with caspase- 8 activation by FADD. Additionally, IAPs can directly prevent caspase- 9 and caspase- 3 activities [79, 83-85].

Apoptosis can result from two circumstances: when a cell fails to receive survival signals and/or when death is actively induced by a death signal [86-89]. It can be triggered in different cells in response to a variety of stimuli and result in the activation of caspases, which act on several intracellular substrates including key housekeeping proteins to uphold the irreversible cell death process. Among the targets of caspases is the inhibitor of caspase-activated DNase (ICAD), which is degraded by caspase-3 [90]. Caspase-3 also cleaves DNA-fragmentation factor (DFF) 45 in the heterodimeric complex DFF40/DFF45. Proteolysis of DFF45 dissociates DFF40 molecules, which oligomerize and translocate into the nucleus to degrade DNA. DNA-dependent protein kinase (DNA-PK), which is part of the cellular DNA repair system, is another substrate for caspase-3 that is degraded following nuclear translocation of caspase-3. Degradation of DNA-PK reduces cell capacity to repair DNA molecule damages allowing its further breakdown by DNases. Caspases also act on different structural components of nuclear envelope and cytoskeletal proteins leading to specific phenotype changes in apoptotic cells [91]. The biological significance of apoptosis could be indicated by the large number of players and intricate signaling pathways involved in this process. Accordingly, apoptosis has been shown to have a regulatory effect on immune system maturation and homeostasis, and hence defects in this process devastate induction of tolerance to frequently encountered self-antigens and contribute to autoimmune pathologies.

\section{APOPTOSIS IN IMMUNE SYSTEM}

In the immune system, apoptosis plays a key role in lymphocyte maturation starting from the early stages of the process in the central lymphoid compartment. This role continues afterward to maintain immune system homeostasis as well as peripheral immune tolerance by removing both autoreactive lymphocytes and those immune cells that excessively remain activated after the termination of an immune response. Apoptosis occurs extensively during different stages of lymphocyte development. It is estimated, for instance, that only $2-4 \%$ of developing T-cells leave the thymus every day as mature cells [15]. This reflects the concerted selection process through which those cells presenting inappropriate receptor specificities are deleted from the immune cells repertoire, and also indicates the importance of the regulatory effect of apoptotic cell death on normal functioning of immune system. Apoptosis can also influence the generation of self-antigens through the modifications that occur during this process [92]. These modifications (mostly proteolytic cleavage and phosphorylation) of self-peptides change the way they are processed thereby allowing new epitopes to be presented to T-cells. Also, efficient clearance of apoptotic cells is another important issue whose abnormalities can lead to autoimmunity due to increased exposure of phagocytic cells to overloading amounts of self-antigens $[93,94]$.

\section{The Role of Apoptosis in Lymphocyte Maturation}

In the course of development, lymphocytes pass through several ordered stages that serve as checkpoints to monitor the maturation process of T- and B-cells. These stages comprise various steps in the expression of functional antigen receptor genes as well as other cell surface and intracellular proteins. Naive immune cells frequently rearrange their genes to assemble normal-functioning interactive receptor molecules. A productive gene rearrangement leads to the formation of a receptor that serves as a signal for the cell to progress to the next developmental stage. The successful assembly of efficient antigen-specific receptors, TCRs and immunoglobulins for the B-cells will characterize the final features of different types of committed B- and T-cells. To pass through these developmental screening led by survival signals and apoptosis, B-cells have to successfully rearrange the immunoglobulin heavy-chain locus and one of the two light-chain kappa or lambda loci. T-cells rearrange either $\alpha$-chain and $\beta$-chain loci to produce a $\alpha / \beta$ T-cell, or $\gamma$-chain and $\delta$-chain loci to produce a $\gamma / \delta$ T-cell. These distinct lineages of T-cells have different types of TCRs. The $\alpha / \beta$ T-cells will later express one of the two coreceptor molecules and develop into two distinct functional subsets, $\mathrm{CD} 4^{+}$and $\mathrm{CD} 8^{+}$single-positive T-cells. At this early stage, those cells that fail to make the productive rearrangements are destined to undergo apoptosis. Some immature Tcells present receptors that cannot recognize self-MHC molecules and hence fail to be positively selected. The lymphocyte precursors that fail to receive environmental survival signals (growth factors, cytokines, and cell-surface molecules) via their newly-expressing receptors undergo the apoptosis process called "death by neglect". Nevertheless, since these cells are not capable of recognizing selfMHC peptide complexes and therefore lack the ability to generate an autoimmune response, impairment in apoptosis at this stage is unlikely to culminate in any autoimmune condition.

Further steps include negative and positive selection of lymphocytes in which those lymphocytes that strongly react with selfcomponents are eliminated (negative selection), whereas the T- and B-cell clones harboring receptors with a low affinity to selfantigens undergo positive selection. The negative selection process occurs through apoptosis of "self"-reactive lymphocytes, resulting in the preservation of the central tolerance. Any defect in this welldesigned process leads to accumulation of autoreactive T- and Bcells culminating in the development of autoimmune disorders. The mechanism(s) of apoptotic cell death underlying negative selection is not clearly known, yet it is postulated that proapoptotic protein Bim plays a role in this process, most likely through its transcriptional activation induced following strong ligand/TCR interaction [95].

\section{Apoptosis and Peripheral Lymphocyte Homeostasis}

As mentioned earlier, the immune system is one of the most dynamic biological structure whose fine homeostasis is maintained through various mechanisms including the balance between persistent synthesis and deletion of lymphocytes in the course of negative selection, death by neglect, and activation-induced cell death (AICD) in the central and peripheral lymphoid organs. Normal physiology of the immune system is based on the overproduction of 
immune cells followed by the selective deletion of the majority of cells and keeping the most effective ones in the immune system repertoire. This extensive decline in the number of immune cells is constantly regulated by apoptotic processes. Activated T-cells simultaneously express Fas and FasL [96]. This ligand/receptor coexpression makes T-cells sensitive to apoptosis, which can be initiated either by the interaction of Fas and FasL of the same cell or of different cells. Activated B-cells also induce the expression of Fas, which makes them susceptible to cell death via the Fas-dependent death pathway $[97,98]$.

In addition to the existence of regulatory checkpoints in the central lymphoid organs, lymphocytes are functionally monitored after they migrate to the periphery. Upon encountering an antigen, specific clones of lymphocytes proliferate to generate effector cells. This antigen/receptor binding is highly specific and induces the activation of lymphocytes in association with costimulatory signals. These costimulatory signals are required for the inhibition of apoptosis processes in activated immune cells by inducing NF- $\kappa \mathrm{B}$ signaling [99]. NF- $\mathrm{BB}$, a member of the Rel family of transcription factors, is best known for its crucial regulatory influence on both innate and adaptive immunity. When activated through TCR and $\mathrm{BCR}, \mathrm{NF}-\mathrm{kB}$ upregulates the expression of antiapoptotic genes including $\mathrm{Bcl}-\mathrm{X}_{\mathrm{L}}$, thereby supporting $\mathrm{T}$ - and $\mathrm{B}$-cell survival. Transcriptional activation of these antiapoptotic genes also allows the proliferation of antigen-specific T-cell clones. This effect is induced by synthesis of different cytokines such as IL-2 and GM-CSF. In the absence of costimulatory signals to activate NF- $\mathrm{KB}$ signaling with prosurvival effect, as is seen in the exposure of naive T-cells to self-antigens, apoptosis can be induced through AICD processes, leading to elimination of T-cells that respond to self-antigens. In addition to receptor-mediated death in immature immune cells, death by neglect also seems to have a role in eliminating the activated mature lymphocytes and resizing the immune cell pool after termination of an immune response. There are also some alternative mechanisms known to induce cell death in autoreactive Tlymphocytes including the upregulation of $\mathrm{p} 73$, mediated by E2F-1 [100].

AICD is one of the mechanisms responsible for maintaining peripheral tolerance to self-constituents. In AICD, apoptosis is induced by repeated TCR stimulation as a result of Fas/FasL binding. In this process, activated T-cells expressing both Fas and FasL undergo cell death either by themselves or through interaction with each other. Mature Fas protein consists of three domains: a cysteine rich extracellular domain, a short transmembrane domain, and a cytoplasmic domain. Fas is widely expressed on the surface of many different types of cells, where it is found in its monomeric form. Ligation of FasL to its receptor induces trimerization of Fas and recruitment of adaptor protein, FADD, which binds to the cytoplasmic part of Fas through interactions between their respective DDs $[10,101]$. Further recruitment of procaspase- 8 and its interaction with FADD through their death effector domains forms the functional DISC, which in turn promotes activation of downstream caspases cascade and proceeds apoptosis.

There are several mechanisms that control Fas/FasL-mediated cell death, thereby regulating the susceptibility of T-cells to AICD. TCR-inducible expression of FasL is regulated predominantly at the transcriptional level. The major transcription factors involved in this process include nuclear factor of activated T-cells (NF-AT), $\mathrm{NF}-\kappa \mathrm{B}$, and interferon regulatory factors (IRFs) [102-105]. FasL expression is also regulated by several members of protein tyrosine kinases (PTKs) including Lck, ZAP-70, PKC and certain members of MAPK family [106, 107]. PTKs are not only required for T-cell activation but also have an important role in T-cell apoptosis [108, 109]. In addition to the expression of FasL, Fas-mediated apoptosis seems to be regulated by c-FLIP, which interferes with the interaction of caspase-8/FLICE with FADD. However, since Fas-mediated cell death, but not AICD, is suppressed in c-FLIP ${ }_{\mathrm{L}}$ (one of the two endogenous forms of c-FLIP) transgenic mice, the role of c-FLIP in AICD remains controversial [110].

Fas-mediated apoptosis does not seem to be involved in negative and positive selection of T-lymphocytes. This was concluded by observing T-cell development in intact in lpr-and gld-mutant mice which lack functional Fas proteins [111]. Fas mutations, however, confer autoimmunity and increased lymphocyte populations in the periphery. This effect has been shown in mice models deficient in Fas or FasL that develop lymphoproliferative disorder [112, 113]. This is mainly due to the very inefficient elimination of T-, and B-cell clones during the downregulation of a specific immune response, after the pathogen has been removed. Moreover, stimulation of Fas-mediated AICD in experimental autoimmune encephalomyelitis (EAE), the experimental model of multiple sclerosis in mouse, generates a spontaneous remission in the course of the disease [112, 113], indicating the involvement of defective Fasmediated cell death in autoimmune pathogenesis of this disease. However, the variability of the phenotypes in patients harboring the identical Fas mutations provide evidence for the presence of other factors influencing the effect of these mutations [114].

Fas-mediated apoptosis is also a key mechanism for effector CTLs to kill the cells infected by viruses. After recognition of viral peptides presented in association with MHC class I molecules, activated CTLs induce the death process in virus-containing cells via Fas/FasL interaction as well as activation of serine proteases such as granzyme B in CTLs [115]. Granzyme B is also known to cleave several self-antigens during CTL-induced apoptosis [116-118]. This effect is important as it can provide the chance for the new autoantigenic products to be presented in context with viral antigens that may mislead the immune system to breakdown the self-tolerance [119].

\section{CLEARANCE OF APOPTOTIC CELL AND AUTOIMMU- NITY}

During apoptosis, the plasma membrane and intracellular constituents of the cell undergo many changes that may bestow novel immunogenic properties to apoptotic cells. Rearrangement of cell membrane phospholipids confers new binding characteristics and promotes formation of new complexes that may increase the immunogenicity of cell surface and triggers development of autoimmune response and generation of autoantibodies [120, 121]. Similarly, modification of self-antigens during apoptosis may affect the antigenic features of intracellular components that may affect their further processing and recognition by MHC class II molecules. Many of these apoptosis-associated alterations occur during selection of T- and B-lymphocytes, leading to induction of proper selftolerance; however, some of these changes create new epitopes to which the immune system is not tolerant. For instance, it has been shown that cleavage of self-proteins and production of neo-antigens by granzyme B during CTL-induced apoptosis generates new immunogenic peptides which are able to raise an autoimmune reaction $[8,116]$. Cleavage of self-peptide substrates by caspases along with other modifications that influence susceptibility of these peptides to proteolytic cleavage serve as other sources to create new epitopes $[122,123]$. The variety of ways by which ubiquitous self-antigens are processed during apoptosis leads to the generation of different immunogenic epitopes from an identical self-peptide. Each of these neoantigens could be specific to a given autoimmune disease and are recognized by autoantibodies that are distinctively reactive to these epitopes [9].

Another issue making apoptotic cells more immunogenic is redistribution of autoantigens that are normally sequestered inside the cell to the surface of apoptotic cells [124]. These antigens are able to trigger an autoimmune response if not cleared properly. Under normal circumstances apoptotic cells are rapidly cleared by macrophages, DCs, and non-specific phagocytes in surrounding tissues. 
This non-inflammatory process is mediated through the interaction between the specific receptors on the surfaces of both phagocytic and apoptotic cells as well as circulating proteins. These include membrane-bound receptor tyrosine kinases Mer, Axl, and Tyro3, which are expressed on the surfaces of macrophages and mononuclear cells $[125,126]$. Recognition and clearance of apoptotic cells is mediated by a variety of molecules that act as "bridges" to promote the interaction between effector phagocytes and the cells being removed. These adaptor molecules such as MFG-E8, annexin I, Protein S, and Gas6 bind to the apoptotic cell surface through phosphotidylserine (PS) and other cell surface elements, allowing their recognition by receptors on macrophages and DCs [127-130]. Phagocytic cells bind to Gas6 and Protein S through Mer, Axl, and Tyro3 receptors on their surface, thereby interacting with apoptotic cells and proceed their clearance. Another molecule shown to be involved in the recognition of clearance of apoptotic cells is C1q, which binds to apoptotic cells and mediates phagocytosis via either interacting with specific receptors on the surface of macrophages $[61,131]$, or by activating the classical complement pathway [132]. $\mathrm{C} 1 \mathrm{q}$ interacts either directly with specific receptors such as $\mathrm{C} 1 \mathrm{qR} \mathrm{R}_{\mathrm{P}}$ on the surface of macrophages, or it may bind to adaptor molecules such as calreticulin, which in turn binds to CD91 on macrophages and promotes uptake of apoptotic cells [61, 62]. Any impairment and delay in efficient removal of apoptotic residues increases the chance of circulating immune cells to recognize and react to new autoantigens, thereby triggering the cascade of destructive immune reaction. Importance of efficient and complete removal of apoptotic residues in maintaining self-tolerance has been evidenced by several studies including the generation of autoantibodies against intracellular self-antigens in mice immunized with large doses of apoptotic cells [133, 134]. Additionally, development of a lupus-like autoimmune phenotype in MFG-E8 knockout mice [135] as well as mice deficient in expressing cellular-Mer receptor [136] supports these findings. Development of antinuclear antibodies and glomerulonephritis pathology in C1q-deficient mice [57] also indicates the role of apoptotic cell clearance in protecting against development of autoimmunity.

\section{AUTOIMMUNE DISORDERS AND APOPTOSIS}

Autoimmune diseases affect 3-5\% of the population [137], and although molecularly and clinically heterogeneous, they could be classified into organ-specific or systemic disorders. The pathogenesis of autoimmune disorders is the presence of self-reactive lymphocytes and the persistent autoreactive response against selfcomponents. This is due to either enhanced survival signals, impaired death pathways in autoreactive lymphocytes, or in some instances, increased sensitivity to apoptosis in target tissues and results in breakdown in central or peripheral immune tolerance.

In organ-specific disorders, the autoimmune reaction develops against an autoantigen that is exclusively found in a certain tissue and the autoimmune pathology is restricted to that certain tissue. For instance, in IDDM, the autoimmune response is directed against the antigens of insulin-producing $\beta$ cells in the pancreas [138], whereas in Graves' disease autoantibodies target different thyroidspecific proteins including thyrotropin receptor [139]. In systemic disorders an autoimmune reaction develops against ubiquitous antigens and leads to a more generalized pattern of disease expression. For instance, antibodies reacting with epitopes on conserved molecules such as dsDNA, phospholipids, and phospholipid-binding proteins can be found in SLE patients, in whom multiple systems including skin, joints, brain, heart, lungs, kidneys, and serosal membranes are affected [140, 141]. Organ-specific autoimmune diseases are frequently found in combination with each other in a single individual, as is seen in autoimmune thyroid diseases that are frequently associated with other autoimmune disorders including vitiligo [142, 143]. Similarly, systemic disorders such as SLE and primary Sjögren's syndrome can coexist within the same person or among different members of a family [144, 145].

Defective apoptosis processes, either accelerated or reduced, has been shown to be associated with autoimmune conditions. Two best-known examples for this include autoimmune lymphoproliferative syndrome (ALPS) with insufficient apoptosis of activated immune cells and IDDM in which death level of $\beta$ islet cells is increased. This is also shown by failure in self-tolerance and development of autoimmunity in both mice and human with inherited defects in Fas or FasL. In IDDM, Fas-mediated apoptosis of pancreatic $\beta$ cells is enhanced [146], while in ALPS impaired expression of Fas contributes to the expanded population of $\mathrm{T}$ lymphocytes [112]. Mutations in Fas/FasL have also been shown to be associated with some cases of SLE [112]. Accordingly, mice models mutant in $l p r$ and gld genes, which encode Fas and FasL molecules, also show ineffective B- and T-cell tolerance and present a lupus-like phenotype [147]. While these data support the involvement of Fas signaling in maintaining self-tolerance and deletion of autoreactive T-lymphocytes, other studies suggest the association of other polymorphic genes in addition to Fas mutations with autoimmune process.

$\mathrm{Bim}$ is a proapoptotic $\mathrm{BH} 3$-only member of the $\mathrm{Bcl}-2$ family that promotes apoptosis by binding to and antagonizing the antiapoptotic members of the family including $\mathrm{Bcl}-\mathrm{X}_{\mathrm{L}}$ and $\mathrm{Bcl}-2$ itself [148]. The finding that Bim knockout mice $\left(\mathrm{Bim}^{-1}\right)$ develop an autoimmune kidney disorder 149] along with the progression of a SLE-like phenotype in Bcl-2 transgenic mice [150, 151 indicates that impeding cell death may contribute to the pathogenesis of autoimmunity. Consistent with this, Bim-deficient DCs show decreased level of cell death and are able to strongly induce T-cell activation and promote production of autoantibodies [152]. Moreover, inhibition of COX2/PTGS2, whose significant upregulation in SLE patients confers resistance to anergy and apoptosis in activated T-cells induces apoptosis in these anergy-resistant T-lymphocytes by enhancing Fas-mediated signaling and decreasing the level of prosurvival molecule FLIP [153]. Moreover, DNase-1 deficient mice exhibit a lupus-like autoimmune phenotype in a dose dependent manner with autoantibodies against nuclear antigens [154]. This is assumed to be a result of insufficient DNA degradation and clearance in sites of high cellular turn over which lead to the generation of an autoimmune reaction against DNA antigens.

The notion that the apoptosis process is unique in each cell due to the way it is induced, the type of the cell and its microenvironment may explain some of the complex features of autoimmune pathogenesis. For instance, generation of distinct immunogenic epitopes during apoptosis results in various phenotypes of separate autoimmune disorders in which a common antigen is the target of different autoantibodies. U1-70-kD snRNA is an example against which the autoimmune reaction is mounted in patients with cutaneous manifestations of lupus, Raynaud's phenomenon, and scleroderma. It has been shown indeed that autoantibodies from these patients recognize differently processed forms of the protein [9].

Considering the diversity of the components in the relationship between apoptosis and autoreactivity, contribution of the apoptotic process to the pathogenesis of autoimmune disorders needs still further investigation. The increasing amount of knowledge provides better insight into the interactive players and the mechanisms by which they contribute to the development of autoimmunity and hopefully lead us to new targeting approaches for more effective therapies against these diseases.

\section{THERAPEUTIC APPROACHES TO AUTOIMMUNE DIS- EASES}

During the last decade, new biotherapies have been developed for the treatment of autoimmune disorders that target various com- 
ponents of an immune response. These include antigenic peptides, effector cells such as macrophages, DCs, NKs and self-reactive Tand B-cells, various cytokines and cell surface molecules, as well as genes encoding these molecules. These therapeutic approaches have been based on either active induction of tolerance or blocking pathways contributing to autoimmunity. The latter may be achieved either by interfering with survival and proliferation signaling of autoreactive cells or inhibiting their activation through blocking their costimulatory partners and also by strengthening the regulatory mechanisms to suppress an abnormal immune response. These methods have been associated with various extents of success in different autoimmune diseases and have proven to be variously beneficial to certain population of patients.

Self-reactive B-cells and the autoantibodies against selfantigens have been among the first targets for treatment of autoimmune diseases. Removal of autoantibodies from the circulation (plasmapheresis) has still a place in the treatment of diseases such as cryoglobulinemia; however it has not shown acceptable results in other autoimmune disorders. Active induction of self-tolerance was primarily initiated by administrating proteins that resemble those being targeted by autoaggressive cells. The basic concept of peptide-tolerance therapy is to educate immune system to tolerate these peptides by being exposed to them. This systemic exposure to autoantigens, although yielded encouraging results in some experiments [155-157], has not shown to be successful in established cases of autoimmune disorders [158] and even led to induction of autoimmunity in some experimental models [159].

Various cytokines secreted by immune cells have also been targeted to modulate an immune response. TNF, ILs and IFNs, which are involved in different pathways and contribute to pathogenesis of several autoimmune processes, have been frequently investigated. The effect of interfering with the signaling pathways of these cytokines have been tested by the development of a variety of anticytokine agents some of which are currently in the market or are being assessed in clinical trials of autoimmune diseases. Some of these anti-cytokine compounds include etanercept/enbrel, adalimumab/humira, infliximab/remicade, certolizumab pegol/cimzia, alefacept /amevive, avonex, and betaseron, which are used as therapeutic agents in autoimmune diseases such as RA, psoriasis, MS and Crohn's disease [160-164]. These drugs have shown beneficial in subsiding inflammation associated with some of the autoimmune diseases; however, they were effective only in a subset of patients. One cytokine of TNF family, called B-cell-activating factor of the TNF family (BAFF), is an essential component of B-cell survival and maturation [165-167]. The level of BAFF is elevated in the sera of patients with some autoimmune disorders such as SLE [168], RA [169] and Sjögren's syndrome [170] and also BAFF-transgenic mice exhibit a SLE-like phenotype [171]. This excess amount of BAFF might provide B-cells with extra survival signals and prevent apoptosis in these cells [172]. Belimumab (LymphoStat-B) is a human monoclonal antibody $(\mathrm{mAb})$ that specifically binds and neutralizes the soluble BAFF thereby interferes with the normal development of B-cells leading to depletion of B-lymphocytes populations. Belimumab has shown to effectively reduce the number of pheripheral B-cells in early phases of clinical trials of some autoimmune diseases as well as in experimental disease models of animal [173].

IL-6 which is a multifunctional cytokine playing role in B-cell differentiation and activation, T-cell function and B-/T-cells interaction [174] is another cytokine being targeted in autoimmunity. Overproduction of IL-6 has been observed in autoimmune diseases including RA and Crohn's disease [175, 176]. Involvement of IL-6 in the pathogenesis of autoimmunity has also been investigated in IL-6-deficient mice that are resistant to collagen-induced arthritis $[177,178]$. The humanized $\mathrm{mAb}$, tocilizumab/MRA, which binds to IL-6 receptor and inhibits its signaling pathway has been effective in ameliorating some of these autoimmune diseases in clinical trials
$[179,180]$ as well as in some animal models [181-183]. IL-1 is another cytokine whose upregulation has been shown to be associated with autoimmune disease activity [184]. Anakinra/kineret is a recombinant $\mathrm{mAb}$ to IL-1 receptor, which has shown beneficial to patients with RA and lupus arthritis in different clinical trials [185188] although its short half-life has constrained its clinical efficacy [189]. Other cytokines have also been studied in autoimmune diseases some of which have shown to be overproduced in disease state [190].

Recently, cell surface molecules and the interactions between different components of an immune response have been studied. In one approach, specific targeting of CD20 antigen by a mAb, rituximab, has been used in clinical trials of autoimmune diseases such as autoimmune cytopenias, RA, SLE and MS to deplete autoreactive B-cell population [191-194]. CD20 is a nonglycosylated phosphoprotein which is expressed on the surface of more than $95 \%$ of B-cells at different stages of their maturation from PreB-cells to immunoblasts [195]. Rituximab binds to the CD20 receptor and induces cytotoxicity via a combination of pathways including complement-mediated lysis, and induction of apoptosis that results in strong depletion of CD20-positive B-cells [196]. Treatment with rituximab evoked dramatic results in some trials, nonetheless, not all the patients respond well to this therapy and in the rest the period during which B-cells are depleted varies from a few months to few years. CD22 is another B-cell surface marker which blocking it's signaling by humanized anti-CD22 mAb, epratuzumab, has demonstrated to effectively promote B-cell depletion in patients with SLE and primary Sjögren's syndrome [197, 198].

T-cells and T-cell-mediated pathways contributing to autoimmunity are other targets of immunomodulation. The important role of autoreactive T-cells in the pathogenesis of organ-specific autoimmune diseases was demonstrated by induction of certain experimental autoimmune diseases following the transfer of activated autoaggressive T-cells into healthy syngeneic animals [199]. In another observation, autoreactive T-cells were isolated from the naive animals that could transfer EAE in syngeneic animals [200]. While the latter finding evidences the fact that autoreactive cells are part of normal immune system, it may indicate that eliminating these cells from immune repertoire may not be accomplished. Antigen-selective therapies target the main feature of a T-cell-mediated immune response which is formed by the interaction between antigen-associating MHC on APCs and the TCR on T-cells. In one of these attempts, an autoantigenic peptide is either modified in such a way that the MHC-binding ability is preserved whereas introducing some amino acid changes alters the capacity of these peptides to fully activate T-cells [201], or they are presented in the absence of costimulatory molecules [202]. Subsequently, stimulation by these altered peptide ligands (APLs) may lead to a shift from $T_{h} 1$ to $T_{h} 2$ and their produced cytokines or induce functional inactivation/anergy to the epitopes being presented [203, 204]. The following shift in the production of $\mathrm{T}_{\mathrm{h}} 1$-associated cytokines to $\mathrm{T}_{\mathrm{h}} 2$-type cytokines is assumed to have a protective role in autoimmune disorders. Whereas this is the case in some diseases such as MS [205], it resulted in the progression of autoimmunity in some other studies [206, 207].

Inhibiting the activation of autoreactive T-cells might also be achieved through interference with costimulatory signals which are necessary for T-cell-mediated immune responses. Treatment with CTLA4Ig mAb has shown to prevent disease progression in animal models of SLE [208] and EAE [209]. Moreover, it has shown to lower disease activity in patients with psoriasis [210] and RA [211]. Abatacept (Orencia), a newly-approved drug for the treatment of patients with RA, is a recombinant human CTLA4-IgG1 protein, which selectively binds B7 family on APCs and inhibit their interaction with CD28 on T-cells thereby inhibits CD28-mediated signaling and activation of T-cells. Abatacept has shown to effectively reduce the signs and symptoms of the active disease in RA cases 
and significantly improve the quality of life in these patients [212, 213].

Anther costimulatory pathway being modulated is CD40/ CD154 that has been implicated in immunopathogenesis of certain autoimmune dieases [214]. CD40 is a membrane receptor of the TNF-R superfamily that is expressed on APCs and interacts with its ligand, CD154, on activated T-cells. Blocking CD40-CD154 interactions has been associated with reducing disease activity in animal models of several diseases such as IDDM [215], collagen-induced arthritis [216], SLE [217], experimental autoimmune glomerulonephritis [218], and EAE [219]. Moreover, inhibiting CD40/CD40 ligand signaling by mAbs has been associated with acceptable therapeutic results in several clinical trials [220-222]. However, a clinical trial with anti-CD154 in MS patients was stopped since the unexpected side effects were observed during the course of therapy [223].

Another class of immune therapy relies on strengthening the physiological immune response through vaccination approaches. The basic idea here is the reinjection of self-reactive T-cell clones following the isolation and inactivation of these cells to stimulate endogenous regulatory pathways via TCR-specific $\mathrm{CD} 8^{+}$suppressor cells [224-227]. In a similar approach, the synthetic peptides of TCR hypervariable regions (CDR) of autoreactive T-cells can be used for the immunization [228, 229]. This is based on the observation that in several animal models of autoimmune diseases antigen receptors of autoaggressive T-cells are formed by a limited number of CDR regions [230, 231]. Immunizing animal models with synthetic peptides corresponding to CDR3 [228] or CDR2 [229] segment of TCR of the T-cells which are activated against myelin basic protein (MBP) conferred resistant to the following induction of EAE and promoted recovery from the disease [232]. This approach has also been used in pilot clinical trials to immunize MS patients with either attenuated autologous MBP-reactive T-cells [233-235] or synthetic peptides [236, 237]. Results of these and similar studies show a significant reduction in the population of disease-associated T-cells and indicate a protective effect against the disease, yet further evidence need to be achieved to prove the safety and efficacy of this approach in treating affected patients.

Another line of therapeutic approaches includes gene transfer methods, which have gained extensive attention in recent years. Due to the involvement of multiple components in an immune/autoimmune response, there is a wide range of genes whose products as either regulatory or inhibitory molecules can be contemplated as potential targets to treat autoimmune disorders. These may include genes involved in regulating $\mathrm{T}$ - and B-cell responses, different ligands and receptors, components of complement system, enzymes, TCR- and BCR-associated signaling molecules, as well as apoptosis encoding genes. However, since most of autoimmune diseases are not single-gene disorders and instead are caused by a set of genes, combination therapy may be required for generating appropriate results.

Gene therapy may be advantageous to other approaches in that it can confer long-term and constant source of therapeutic agent. Additionally, it averts some of the limitations of other therapeutic methods such as repeated administrations, short half-life, toxic effects of systemic administration as well as the chance of the drug being neutralized by the host immune system. Either local or systemic transfer of naked DNA or recombinant vector can be used to deliver the target gene into the body. Overexpression of corresponding gene can be achieved either in vivo by direct injection of the vector or ex vivo through transduction of specific cell types such as APCs, DCs, tissue-specific fibroblasts, and autoantigen-reactive T-cells followed by their reinjection into the host. Recent development of various "on demand", regulated gene expression systems provides further opportunities for fine-tuning of such approaches [238].
In one of these gene-modulatory approaches the B7/CD28 costimulatory pathway is targeted and inhibited via the delivery of CTLA4Ig gene. Intravenous injection of a recombinant adenovirus vector containing CTLA4IgG into lpr mice has been associated with complete suppression of nephritis in these mice [239]. Also, intravenous injection of CTLA4IgG-containing vector in EAE model [240] as well as intraarticular injection of the vector in mice with collagen induced arthritis [241] was able to reduce the severity and/or inhibit the development of the disease.

Various cytokines including TNF, TGF $\beta 1$, IL-1, IL-4 and IL-10 have also been targeted by gene transfer methods. The local injection of expression plasmids encoding immunosuppressive cytokines such as IL-4, TGF $\beta 1$ and IL-10 has been shown to increase the level of these cytokines in circulation, enhance humoral and cellular immune responses and protect against several autoimmune diseases in animal models [242-247]. Antagonizing the cytokines with proinflammatory effects has also demonstrated to prevent progression of the disease in experimental autoimmune diseases such as arthritis, IDDM and SLE [248-251]. Also, ex vivo gene transfer of these cytokines or cytokine inhibitory proteins through modifying antigen-specific T-cells and fibroblasts has shown to be an effective therapy in induced forms of arthritis in animal models [252, 253].

Delivery of genes involved in apoptosis has also demonstrated promissing results in ameliorating the symptoms in some autoimmune disorders. Delivery of FasL gene into affected joint in murine autoimmune arthritis inhibited the production of proinflammatory cytokines such as IFN $\gamma$ and led to apoptosis of hyperplasic synovial cells $[254,255]$. Also, systemic administration of FasL through modified DCs in mice with established arthritis has demonstrated significant improvement in the course of the disease in treated mice $[255,256]$. Local injection of vectors expressing FasL gene induced apoptosis of infiltrating T-cells in experimental autoimmune thyroiditis model [257]. In another study, transfection of human pancreatic $\beta$-cells with Bcl- 2 encoding vector protected these cells from cytokine-induced apoptosis and subsequent destruction, and preserved functional insulin secretion [258].

Gene transfer approaches, although having great potentials, are still young and need to be evidenced to be safe and effective in human immunotherapy. The fact that targeted therapy of autoimmune diseases has been accompanied with various levels of efficacy in different cases of a disease indicates the presence of a set of pathways contributing to autoimmunity. This may lead us to the discovery of new molecules and pathways that influence the result of treatment with a certain drug and implies the necessity of combination therapy in cases resistant to a certain therapeutic approach.

\section{CONCLUDING REMARKS}

Despite the vast amount of knowledge gained during the last decades and through recent advances, the underlying events and exact mechanisms leading to self-tolerance breakdown and autoreactivity are still poorly understood. Many questions still await answers in the clarification of the pathogenesis and the combinatory effect of host- and environmental-related factors in developing a self-directed immune response. Also, certain features of autoimmune disorders such as disproportionate distribution of the disease being more frequently found in young and female individuals with some tissues appearing more commonly as targets for autoimmune reaction should to be further addressed. Although several susceptibility loci have been proposed, there are inconsistencies in these reports that remain to be resolved in future works. This is in part due to different allelic background and phenotypic dissimilarities between comparable diseases in different populations. Additionally, experimental insufficiencies such as incoherent statistical studies and genotyping errors are also responsible for this discrepancy.

Error in antigen presenting processes underlies the pathogenesis of autoimmunity. Whereas auto-antibodies can be used to identify 
the targets of the autoimmune process, owing to the nature of T-cell ligands, identification of targets in T-cell-mediated autoimmune response is more difficult. In recent years, studies have uncovered the association of different genes and their variants with autoimmunity, yet the exact biochemical pathways affected by the gene product are uncertain. Moreover, the influence of non-inherent factors on initiation and progression to autoimmunity should be addressed by large prospective longitudinal studies.

Targeted stimulation of the adaptive immune response, called vaccination, has been one of the earliest successful interventions with immune system function. This implies and raises hope that antigen-specific suppression of an adaptive immune response along with targeting the key components in innate immune system may contribute to the treatment of certain human autoimmune diseases. Using the knowledge obtained from microarray and large-scale genome analyses will assist us to characterize new targets for therapeutic approaches [259, 260]. Furthermore, haplotype and firstdegree relative studies will aid us to establish a set of biomolecules to be applied in clinical sciences as more personalized medicine in autoimmune diseases.

\section{ACKNOWLEDGEMENTS}

M.L. thankfully acknowledges the support by the CFI-Canada Research Chair program, MICH-, CCMF-, MHRC-, and CIHRfoundation -financed programs. S.P. thankfully acknowledges the support by the CCMF- and by CIHR-training fellowships. I.R., and S.G. thankfully acknowledge the support by MHRC-, and CCMFfunded fellowships.

\section{ABBREVIATIONS}

\begin{tabular}{|c|c|}
\hline AICD & $=$ Activation-induced cell death \\
\hline AP-1 & $=$ Activator protein -1 \\
\hline AIRE & $=$ Autoimmune regulator \\
\hline APC & $=$ Antigen presenting cell \\
\hline Apaf-1 & $=$ Apoplectic protease activating factor- 1 \\
\hline BCR & $=\mathrm{B}$-cell receptor \\
\hline c-FLIP & $=$ Cellular FLICE-like inhibitory protein \\
\hline COX2/PTGS2 & $=$ Cyclooxygenase -2 \\
\hline CTL & $=$ Cytotoxic T-lymphocyte \\
\hline CTLA-4 & $=$ Cytotoxic T-lymphocyte antigen 4 \\
\hline DD & $=$ Death domain \\
\hline DED & $=$ Death effector domain \\
\hline DISC & $=$ Death inducing signaling complex \\
\hline DFF & $=$ DNA-fragmentation factor \\
\hline DNA-PK & $=$ DNA-dependent protein kinase \\
\hline EAE & $=$ Experimental autoimmune encephalomyelitis \\
\hline FasL & $=$ Fas ligand \\
\hline FADD & $=$ Fas-associated death domain protein \\
\hline FCRL3 & $=\mathrm{A}$ member of the $\mathrm{Fc}$ receptor-like family \\
\hline GD & $=$ Grave's disease \\
\hline Gas6 & $=$ Growth arrest-specific gene 6 \\
\hline HLA & $=$ Human leukocyte antigen \\
\hline IAPs & $=$ Inhibitor of apoptosis proteins \\
\hline ICAD & $=$ Inhibitor of caspase-activated DNase \\
\hline IDDM & $=$ Insulin-dependent diabetus mellitus \\
\hline IRFs & $=$ Interferon regulatory factors \\
\hline $\begin{array}{l}\text { U1-70-kD } \\
\text { snRNA }\end{array}$ & $\begin{aligned}= & 70-\mathrm{kD} \text { subunit of the } \mathrm{U} 1 \text { small nuclear ribonu- } \\
& \text { cleoprotein }\end{aligned}$ \\
\hline
\end{tabular}

$\begin{array}{ll}\text { LYP } & =\text { Lymphoid tyrosine phosphatase } \\ \text { MHC } & =\text { Major histocompatibility complex } \\ \text { MFG-E8 } & =\text { Milk fat globule epidermal growth factor } 8 \\ \text { MS } & =\text { Multiple sclerosis } \\ \text { NF-AT } & =\text { Nuclear factor of activated T-cells } \\ \text { NK } & =\text { Natural killer cell } \\ \text { NOD } & =\text { Nucleotide oligomerization domain } \\ \text { PADI } & =\text { Peptidylarginine deaminase } \\ \text { PDCD1 } & =\text { Programmed cell death 1 } \\ \text { PTKs } & =\text { Protein tyrosine kinases } \\ \text { PTPN22 } & =\text { Protein tyrosine phosphatase 22 } \\ \text { RA } & =\text { Rheumatoid arthritis } \\ \text { SNP } & =\text { Single nucleotide polymorphism } \\ \text { SUMO4 } & =\text { Small ubiquitin-like modifier } 4 \\ \text { SLE } & =\text { Systemic lupus erythematosus } \\ \text { TCR } & =\text { T-cell receptor } \\ \text { TLR } & =\text { Toll-like receptor } \\ \text { TGF- } \beta & =\text { Transforming growth factor } \beta \\ 3 \text { UTR } & =3 \text { untranslated region } \\ \text { TNF-R } & =\text { TNF-Receptor } \\ \mathrm{T}_{\text {regs }} & =\text { Regulatory T-cells } \\ & \end{array}$

\section{REFERENCES}

[1] Bottini, N.; Musumeci, L.; Alonso, A.; Rahmouni, S.; Nika, K.; Rostamkhani, M.; MacMurray, J.; Meloni, G.F.; Lucarelli, P.; Pellecchia, M.; Eisenbarth, G.S.; Comings, D.; Mustelin, T. Nat. Genet., 2004, 36(4), 337338 .

[2] Carlton, V.E.; Hu, X.; Chokkalingam, A.P.; Schrodi, S.J.; Brandon, R.; Alexander, H.C.; Chang, M.; Catanese, J.J.; Leong, D.U.; Ardlie, K.G.; Kastner, D.L.; Seldin, M.F.; Criswell, L.A.; Gregersen, P.K.; Beasley, E.; Thomson, G.; Amos, C.I.; Begovich, A.B. Am. J. Hum. Genet., 2005, 77(4), 567-581.

[3] Guo, D.; Li, M.; Zhang, Y.; Yang, P.; Eckenrode, S.; Hopkins, D.; Zheng, W.; Purohit, S.; Podolsky, R.H.; Muir, A.; Wang, J.; Dong, Z.; Brusko, T.; Atkinson, M.; Pozzilli, P.; Zeidler, A.; Raffel, L.J.; Jacob, C.O.; Park, Y.; Serrano-Rios, M.; Larrad, M.T.; Zhang, Z.; Garchon, H.J.; Bach, J.F.; Rotter, J.I.; She, J.X.; Wang, C.Y. Nat. Genet., 2004, 36(8), 837-841.

[4] Kochi, Y.; Yamada, R.; Suzuki, A.; Harley, J.B.; Shirasawa, S.; Sawada, T.; Bae, S.C.; Tokuhiro, S.; Chang, X.; Sekine, A.; Takahashi, A.; Tsunoda, T.; Ohnishi, Y.; Kaufman, K.M.; Kang, C.P.; Kang, C.; Otsubo, S.; Yumura, W.; Mimori, A.; Koike, T.; Nakamura, Y.; Sasazuki, T.; Yamamoto, K. Nat. Genet., 2005, 37(5), 478-485.

[5] Kotsa, K.; Watson, P.F.; Weetman, A.P. Clin. Endocrinol. (Oxf)., 1997, 46(5), 551-554.

[6] Prokunina, L.; Castillejo-Lopez, C.; Oberg, F.; Gunnarsson, I.; Berg, L.; Magnusson, V.; Brookes, A.J.; Tentler, D.; Kristjansdottir, H.; Grondal, G.; Bolstad, A.I.; Svenungsson, E.; Lundberg, I.; Sturfelt, G.; Jonssen, A.; Truedsson, L.; Lima, G.; Alcocer-Varela, J.; Jonsson, R.; Gyllensten, U.B.; Harley, J.B.; Alarcon-Segovia, D.; Steinsson, K.; Alarcon-Riquelme, M.E. Nat. Genet., 2002, 32(4), 666-669.

[7] Sharfe, N.; Dadi, H.K.; Shahar, M.; Roifman, C.M. Proc. Natl. Acad. Sci. USA, 1997, 94(7), 3168-3171.

[8] Casciola-Rosen, L.; Andrade, F.; Ulanet, D.; Wong, W.B.; Rosen, A. J. Exp. Med., 1999, 190(6), 815-826.

[9] Greidinger, E.L.; Casciola-Rosen, L.; Morris, S.M.; Hoffman, R.W.; Rosen, A. Arthritis Rheum., 2000, 43(4), 881-888.

[10] Krammer, P.H. Nature, 2000, 407(6805), 789-795.

[11] Los, M.; Wesselborg, S.; Schulze-Osthoff, K. Immunity, 1999, 10, 629-639.

[12] Nemazee, D.A.; Burki, K. Nature, 1989, 337(6207), 562-566.

[13] Pugliese, A.; Zeller, M.; Fernandez, A. Jr.; Zalcberg, L.J.; Bartlett, R.J.; Ricordi, C.; Pietropaolo, M.; Eisenbarth, G.S.; Bennett, S.T.; Patel, D.D. Nat. Genet., 1997, 15(3), 293-297.

[14] Rathmell, J.C.; Townsend, S.E.; Xu, J.C.; Flavell, R.A.; Goodnow, C.C. Cell, 1996, 87(2), 319-329.

[15] Janeway, C.A.; Travers, P.; Walport, M.; Shlomchik, M. Immunobiology, 5 ed. Garland Publishing: New York, 2001.

[16] Taubert, R.; Schwendemann, J.; Kyewski, B. Eur. J. Immunol., 2007, 37(3), 838-848. 
[17] Falb, D.; Briner, T.J.; Sunshine, G.H.; Bourque, C.R.; Luqman, M.; Gefter, M.L.; Kamradt, T. Eur. J. Immunol., 1996, 26(1), 130-135.

[18] Jenkins, M.K.; Schwartz, R.H. J. Exp. Med., 1987, 165(2), 302-319.

[19] Buer, J.; Lanoue, A.; Franzke, A.; Garcia, C.; von Boehmer, H.; Sarukhan, A. J. Exp. Med., 1998, 187(2), 177-183.

[20] Akkaraju, S.; Ho, W.Y.; Leong, D.; Canaan, K.; Davis, M.M.; Goodnow, C.C. Immunity, 1997, 7(2), 255-271.

[21] Ferber, I.; Schonrich, G.; Schenkel, J.; Mellor, A.L.; Hammerling, G.J.; Arnold, B. Science, 1994, 263(5147), 674-676.

[22] Barker, C.F.; Billingham, R.E. Adv. Immunol., 1977, 25, 1-54.

[23] Grisanti, S.; Ishioka, M.; Kosiewicz, M.; Jiang, L.Q. Invest. Ophthalmol. Vis. Sci., 1997, 38(8), 1619-1626.

[24] Vafiadis, P.; Bennett, S.T.; Todd, J.A.; Nadeau, J.; Grabs, R.; Goodyer, C.G.; Wickramasinghe, S.; Colle, E.; Polychronakos, C. Nat. Genet., 1997, 15(3), 289-292.

[25] Mostarica-Stojkovic, M. Srp. Arh. Celok. Lek., 2005, 133(Suppl 1), 9-15.

[26] Morton, P.A.; Fu, X.T.; Stewart, J.A.; Giacoletto, K.S.; White, S.L.; Leysath, C.E.; Evans, R.J.; Shieh, J.J.; Karr, R.W. J. Immunol., 1996, 156(3), 10471054 .

[27] Jin, Y.; Mailloux, C.M.; Gowan, K.; Riccardi, S.L.; LaBerge, G.; Bennett, D.C.; Fain, P.R.; Spritz, R.A. N. Engl. J. Med., 2007, 356(12), 1216-1225.

[28] Leadbetter, E.A.; Rifkin, I.R.; Hohlbaum, A.M.; Beaudette, B.C.; Shlomchik, M.J.; Marshak-Rothstein, A. Nature, 2002, 416(6881), 603-607.

[29] Eriksson, U.; Ricci, R.; Hunziker, L.; Kurrer, M.O.; Oudit, G.Y.; Watts, T.H.; Sonderegger, I.; Bachmaier, K.; Kopf, M.; Penninger, J.M. Nat. Med., 2003, 9(12), 1484-1490.

[30] Meylan, E.; Tschopp, J.; Karin, M. Nature, 2006, 442(7098), 39-44.

[31] Hyttinen, V.; Kaprio, J.; Kinnunen, L.; Koskenvuo, M.; Tuomilehto, J. Diabetes, 2003, 52(4), 1052-1055.

[32] Ringold, D.A.; Nicoloff, J.T.; Kesler, M.; Davis, H.; Hamilton, A.; Mack, T. Thyroid, 2002, 12(8), 647-653.

[33] Willer, C.J.; Dyment, D.A.; Risch, N.J.; Sadovnick, A.D.; Ebers, G.C. Proc. Natl. Acad. Sci. USA, 2003, $100(22), 12877-12882$.

[34] Hudson, C.A.; Cao, L.; Kasten-Jolly, J.; Kirkwood, J.N.; Lawrence, D.A. J. Toxicol. Environ. Health A, 2003, 66(10), 895-918.

[35] Rozzo, S.J.; Vyse, T.J.; Drake, C.G.; Kotzin, B.L. Proc. Natl. Acad. Sci. USA, 1996, 93(26), 15164-15168.

[36] Fernandez-Mestre, M.T.; Vargas, V.; Montagnani, S.; Cotua, M.; Ogando, V.; Layrisse, Z. Hum. Immunol., 2004, 65(1), 54-59.

[37] Smerdel-Ramoya, A.; Finholt, C.; Lilleby, V.; Gilboe, I.M.; Harbo, H.F.; Maslinski, S.; Forre, O.; Thorsby, E.; Lie, B.A. Rheumatology (Oxford), 2005, 44(11), 1368-1373.

[38] Wei, J.C.; Tsai, W.C.; Lin, H.S.; Tsai, C.Y.; Chou, C.T. Rheumatology (Oxford), 2004, 43(7), 839-842.

[39] Geluk, A.; van Meijgaarden, K.E.; Schloot, N.C.; Drijfhout, J.W.; Ottenhoff, T.H.; Roep, B.O. Diabetes, 1998, 47(10), 1594-1601.

[40] Morel, L.; Tian, X.H.; Croker, B.P.; Wakeland, E.K. Immunity, 1999, 11(2), 131-139.

[41] Newman, B.; Wintle, R.F.; van Oene, M.; Yazdanpanah, M.; Owen, J.; Johnson, B.; Gu, X.; Amos, C.I.; Keystone, E.; Rubin, L.A.; Siminovitch, K.A. Arthritis Rheum., 2005, 52(2), 425-429.

[42] Casciola-Rosen, L.A.; Anhalt, G.J.; Rosen, A. J. Exp. Med., 1995, 182(6), 1625-1634

[43] Hsu, H.L.; Yeh, N.H. J. Cell Sci., 1996, 109 (Pt 2), 277-288.

[44] Rosen, A.; Casciola-Rosen, L.; Wigley, F. Curr. Opin. Rheumatol., 1997, 9(6), 538-543.

[45] Annunziato, F.; Cosmi, L.; Liotta, F.; Lazzeri, E.; Manetti, R.; Vanini, V.; Romagnani, P.; Maggi, E.; Romagnani, S. J. Exp. Med., 2002, 196(3), 379387.

[46] Atabani, S.F.; Thio, C.L.; Divanovic, S.; Trompette, A.; Belkaid, Y.; Thomas, D.L.; Karp, C.L. Eur. J. Immunol., 2005, 35(7), 2157-2162.

[47] Salomon, B.; Bluestone, J.A. Annu. Rev. Immunol., 2001, 19, 225-252.

[48] Han, S.; Li, Y.; Mao, Y.; Xie, Y. Hum. Genet., 2005, 118(1), 123-132.

[49] Suppiah, V.; Alloza, I.; Heggarty, S.; Goris, A.; Dubois, B.; Carton, H.; Vandenbroeck, K. J. Neuroimmunol., 2005, 164(1-2), 148-153.

[50] Vaidya, B.; Imrie, H.; Perros, P.; Young, E.T.; Kelly, W.F.; Carr, D.; Large, D.M.; Toft, A.D.; McCarthy, M.I.; Kendall-Taylor, P.; Pearce, S.H. Hum. Mol. Genet., 1999, 8(7), 1195-1199.

[51] Zhernakova, A.; Eerligh, P.; Barrera, P.; Wesoly, J.Z.; Huizinga, T.W.; Roep, B.O.; Wijmenga, C.; Koeleman, B.P. Hum. Genet., 2005, 118(1), 5866.

[52] Cloutier, J.F.; Veillette, A. J. Exp. Med., 1999, 189(1), 111-121.

[53] Guja, C.; Guja, L.; Nutland, S.; Rance, H.; Todd, J.A.; Ionescu-Tirgoviste, C. Rom. J. Intern. Med., 2004, 42(2), 313-323.

[54] Suzuki, A.; Yamada, R.; Chang, X.; Tokuhiro, S.; Sawada, T.; Suzuki, M.; Nagasaki, M.; Nakayama-Hamada, M.; Kawaida, R.; Ono, M.; Ohtsuki, M.; Furukawa, H.; Yoshino, S.; Yukioka, M.; Tohma, S.; Matsubara, T.; Wakitani, S.; Teshima, R.; Nishioka, Y.; Sekine, A.; Iida, A.; Takahashi, A.; Tsunoda, T.; Nakamura, Y.; Yamamoto, K. Nat. Genet., 2003, 34(4), 395402 .

[55] Booy, E.P.; Kadkhoda, K.; Johar, D.; Bay, G.H.; Los, M. Curr. Med. Chem.Anti-Inflamm. Anti-Allergy Agents, 2005, 4(4), 349-353.
[56] Prokunina, L.; Padyukov, L.; Bennet, A.; de Faire, U.; Wiman, B.; Prince, J.; Alfredsson, L.; Klareskog, L.; Alarcon-Riquelme, M. Arthritis Rheum., 2004, 50(6), 1770-1773.

[57] Botto, M.; Dell'Agnola, C.; Bygrave, A.E.; Thompson, E.M.; Cook, H.T.; Petry, F.; Loos, M.; Pandolfi, P.P.; Walport, M.J. Nat. Genet., 1998, 19(1), 56-59.

[58] Gavanescu, I.; Kessler, B.; Ploegh, H.; Benoist, C.; Mathis, D. Proc. Natl. Acad. Sci. USA, 2007, 104(11), 4583-4587.

[59] Nagafuchi, S.; Katsuta, H.; Koyanagi-Katsuta, R.; Yamasaki, S.; Inoue, Y; Shimoda, K.; Ikeda, Y.; Shindo, M.; Yoshida, E.; Matsuo, T.; Ohno, Y.; Kogawa, K.; Anzai, K.; Kurisaki, H.; Kudoh, J.; Harada, M.; Shimizu, N. Microbiol. Immunol., 2006, 50(12), 979-987.

[60] Nagamine, K.; Peterson, P.; Scott, H.S.; Kudoh, J.; Minoshima, S.; Heino, M.; Krohn, K.J.; Lalioti, M.D.; Mullis, P.E.; Antonarakis, S.E.; Kawasaki, K.; Asakawa, S.; Ito, F.; Shimizu, N. Nat. Genet., 1997, 17(4), 393-398.

[61] Nepomuceno, R.R.; Tenner, A.J. J. Immunol., 1998, 160(4), 1929-1935.

[62] Ogden, C.A.; deCathelineau, A.; Hoffmann, P.R.; Bratton, D.; Ghebrehiwet, B.; Fadok, V.A.; Henson, P.M. J. Exp. Med., 2001, 194(6), 781-795.

[63] Prodeus, A.P.; Goerg, S.; Shen, L.M.; Pozdnyakova, O.O.; Chu, L.; Alicot, E.M.; Goodnow, C.C.; Carroll, M.C. Immunity, 1998, 9(5), 721-731.

[64] Strobel, P.; Murumagi, A.; Klein, R.; Luster, M.; Lahti, M.; Krohn, K.; Schalke, B.; Nix, W.; Gold, R.; Rieckmann, P.; Toyka, K.; Burek, C.; Rosenwald, A.; Muller-Hermelink, H.K.; Pujoll-Borrell, R.; Meager, A. Willcox, N.; Peterson, P.; Marx, A. J. Pathol., 2007, 211(5), 563-571.

[65] Jonsson, G.; Sjoholm, A.G.; Truedsson, L.; Bengtsson, A.A.; Braconier, J.H.; Sturfelt, G. Rheumatology (Oxford), 2007, 46(7), 1133-9.

[66] Szalai, A.J.; Hu, X.; Adams, J.E.; Barnum, S.R. Mol. Immunol., 2007 44(12), 3132-3136

[67] Hengartner, M.O. Nature, 2000, 407(6805), 770-776.

[68] Savill, J.; Fadok, V.; Henson, P.; Haslett, C. Immunol. Today, 1993, 14(3), 131-136.

[69] Mu, W.; Ouyang, X.; Agarwal, A.; Zhang, L.; Long, D.A.; Cruz, P.E.; Roncal, C.A.; Glushakova, O.Y; Chiodo, V.A; Atkinson, M.A; Hauswirth, W.W.; Flotte, T.R.; Rodriguez-Iturbe, B.; Johnson, R.J. J. Am. Soc. Nephrol., 2005, 16(12), 3651-3660.

[70] Preller, V.; Gerber, A.; Wrenger, S.; Togni, M.; Marguet, D.; Tadje, J.; Lendeckel, U.; Rocken, C.; Faust, J.; Neubert, K.; Schraven, B.; Martin, R.; Ansorge, S.; Brocke, S.; Reinhold, D. J. Immunol., 2007, 178(7), 4632-4640. Ruiz, P.A.; Shkoda, A.; Kim, S.C.; Sartor, R.B.; Haller, D. Ann. N. Y. Acad. Sci., 2006, 1072, 389-394.

[72] Los, M.; Van de Craen, M.; Penning, L.C.; Schenk, H.; Westendorp, M Baeuerle, P.A.; Droge, W.; Krammer, P.H.; Fiers, W.; Schulze-Osthoff, K. Nature, 1995, 375, 81-83.

[73] Ashkenazi, A.; Dixit, V.M. Science, 1998, 281(5381), 1305-1308.

[74] Ghavami, S.; Hashemi, M.; Kadkhoda, K.; Alavian, S.M.; Bay, G.H.; Los, M. Med. Sci. Monit., 2005, 11(11), RA337-345.

[75] Banerji, S.; Los, M. Cancer Biol. Ther., 2006, 5(8), 965-966.

[76] Hashemi, M.; Ghavami, S.; Eshraghi, M.; Booy, E.P.; Los, M. Eur. J. Pharm., 2007, 557(1), 9-19.

[77] Hashemi, M.; Karami-Tehrani, F.; Ghavami, S.; Maddika, S.; Los, M. Cell Prolif., 2005, 38(5), 269-285.

[78] Huang, X.; Kurose, A.; Tanaka, T.; Traganos, F.; Dai, W.; Darzynkiewicz, Z. Cancer Biol. Ther., 2006, 5(8), 959-964.

[79] Maddika, S.; Booy, E.P.; Johar, D.; Gibson, S.B.; Ghavami, S.; Los, M. $J$. Cell Sci., 2005, 118(Pt 19), 4485-4493.

[80] Brouckaert, G.; Kalai, M.; Saelens, X.; Vandenabeele, P. In Apoptotic pathways as target for novel therapies in cancer and other diseases. Los, M.; Gibson, S.B. Eds.; Springer Academic Press: New York, 2005

[81] Li, P.; Nijhawan, D.; Budihardjo, I.; Srinivasula, S.M.; Ahmad, M.; Alnemri, E.S.; Wang, X. Cell, 1997, 91(4), 479-489.

[82] Pop, C.; Fitzgerald, P.; Green, D.R.; Salvesen, G.S. Biochemistry, 2007 46(14), 4398-4407.

[83] Cassens, U.; Lewinski, G.; Samraj, A.K.; von Bernuth, H.; Baust, H.; Khazaie, K.; Los, M. Arch. Immunol. Ther. Exp., 2003, 51(1), 19-27.

[84] Muzio, M.; Chinnaiyan, A.M.; Kischkel, F.C.; O'Rourke, K.; Shevchenko, A.; Ni, J.; Scaffidi, C.; Bretz, J.D.; Zhang, M.; Gentz, R.; Mann, M.; Krammer, P.H.; Peter, M.E.; Dixit, V.M. Cell, 1996, 85(6), 817-827.

[85] Roy, N.; Deveraux, Q.L.; Takahashi, R.; Salvesen, G.S.; Reed, J.C. EMBO J., 1997, 16(23), 6914-6925

[86] Booy, E.P.; Johar, D.; Maddika, S.; Pirzada, H.; Sahib, M.M.; Gehrke, I.; Loewen, S.D.; Louis, S.D.; Kadkhoda, K.; Mowat, M.; Los, M. Arch. Immunol. Ther. Exp., 2006, 54, 1-17.

[87] Johnston, J.B.; Navaratnam, S.; Pitz, M.W.; Maniate, J.M.; Wiechec, E.; Baust, H.; Gingerich, J.; Skliris, G.P.; Murphy, L.C.; Los, M. Curr. Med. Chem., 2006, 13, 3483-3492.

[88] Krzemieniecki, K.; Szpyt, E.; Rashedi, I.; Gawron, K.; Los, M. Centr. Eur. J. Biol., 2006, 1(2), 167-182.

[89] Maddika, S.; Ande, S.R.; Panigrahi, S.; Paranjothy, T.; Weglarczyk, K.; Zuse, A.; Eshraghi, M.; Manda, K.D.; Wiechec, E.; Los, M. Drug Resist. Updat., 2007, $10(1-2), 13-29$.

[90] Sakahira, H.; Enari, M.; Nagata, S. Nature, 1998, 391(6662), 96-99.

[91] Nalepa, G.; Zukowska-Szczechowska, E. Wiad. Lek., 2002, 55(1-2), 100106.

[92] Sercarz, E.E. Nat. Immunol., 2002, 3(2), 110-112. 
[93] Gaipl, U.S.; Sheriff, A.; Franz, S.; Munoz, L.E.; Voll, R.E.; Kalden, J.R.; Herrmann, M. Curr. Top. Microbiol. Immunol., 2006, 305, 161-176.

[94] Lauber, K.; Blumenthal, S.G.; Waibel, M.; Wesselborg, S. Mol. Cell., 2004, 14(3), 277-287.

[95] Bouillet, P.; Purton, J.F.; Godfrey, D.I.; Zhang, L.C.; Coultas, L.; Puthalakath, H.; Pellegrini, M.; Cory, S.; Adams, J.M.; Strasser, A. Nature, 2002, 415(6874), 922-926.

[96] Ju, S.T.; Panka, D.J.; Cui, H.; Ettinger, R.; el-Khatib, M.; Sherr, D.H.; Stanger, B.Z.; Marshak-Rothstein, A. Nature, 1995, 373(6513), 444-448.

[97] Berard, M.; Casamayor-Palleja, M.; Billian, G.; Bella, C.; Mondiere, P.; Defrance, T. Immunology, 1999, 98(1), 47-54.

[98] Li-Weber, M.; Krammer, P.H. Semin. Immunol., 2003, 15(3), 145-157.

[99] Liang, Y.; Zhou, Y.; Shen, P. Cell Mol. Immunol., 2004, 1(5), 343-350.

[100] Lissy, N.A.; Davis, P.K.; Irwin, M.; Kaelin, W.G.; Dowdy, S.F. Nature, 2000, 407(6804), 642-645.

[101] Nagata, S.; Golstein, P. Science, 1995, 267(5203), 1449-1456.

[102] Camacho, I.A.; Singh, N.; Hegde, V.L.; Nagarkatti, M.; Nagarkatti, P.S. J. Immunol., 2005, 175(1), 90-103.

[103] Chow, W.A.; Fang, J.J.; Yee, J.K. J. Immunol., 2000, 164(7), 3512-3518.

[104] Latinis, K.M.; Norian, L.A.; Eliason, S.L.; Koretzky, G.A. J. Biol. Chem., 1997, 272(50), 31427-31434.

[105] Demirci, F.Y.; Manzi, S.; Ramsey-Goldman, R.; Minster, R.L.; Kenney, M.; Shaw, P.S.; Dunlop-Thomas, C.M.; Kao, A.H.; Rhew, E.; Bontempo, F.; Kammerer, C.; Kamboh, M.I. Ann. Hum. Genet., 2007, 7l(pt 3), 308-11.

[106] Dong, C.; Yang, D.D.; Wysk, M.; Whitmarsh, A.J.; Davis, R.J.; Flavell, R.A. Science, 1998, 282(5396), 2092-2095.

[107] van den Brink, M.R.; Kapeller, R.; Pratt, J.C.; Chang, J.H.; Burakoff, S.J. J. Biol. Chem., 1999, 274(16), 11178-11185.

[108] Gonzalez-Garcia, A.; L, R.B.; Leonardo, E.; Merida, I.; Martinez, A.C.; Carrera, A.C. J. Immunol., 1997, 158(9), 4104-4112.

[109] Oyaizu, N.; Than, S.; McCloskey, T.W.; Pahwa, S. Biochem. Biophys. Res. Commun., 1995, 213(3), 994-1001.

[110] Lens, S.M.; Kataoka, T.; Fortner, K.A.; Tinel, A.; Ferrero, I.; MacDonald, R.H.; Hahne, M.; Beermann, F.; Attinger, A.; Orbea, H.A.; Budd, R.C.; Tschopp, J. Mol. Cell. Biol., 2002, 22(15), 5419-5433.

[111] Laouar, Y.; Sarukhan, A.; Pasqualetto, V.; Garcia, C.; Ezine, S. Eur. J. Immunol., 1998, 28(3), 1078-1088.

[112] Fisher, G.H.; Rosenberg, F.J.; Straus, S.E.; Dale, J.K.; Middleton, L.A.; Lin, A. Y.; Strober, W.; Lenardo, M.J.; Puck, J.M. Cell, 1995, 81(6), 935-946.

[113] Rieux-Laucat, F.; Le Deist, F.; Hivroz, C.; Roberts, I.A.; Debatin, K.M.; Fischer, A.; de Villartay, J.P. Science, 1995, 268(5215), 1347-1349.

[114] Del-Rey, M.J.; Manzanares, J.; Bosque, A.; Aguilo, J.I.; Gomez-Rial, J.; Roldan, E.; Serrano, A.; Anel, A.; Paz-Artal, E.; Allende, L.M. Immunobiology, 2007, 212(2), 73-83.

[115] Heusel, J.W.; Wesselschmidt, R.L.; Shresta, S.; Russell, J.H.; Ley, T.J. Cell, 1994, 76(6), 977-987.

[116] Andrade, F.; Roy, S.; Nicholson, D.; Thornberry, N.; Rosen, A.; CasciolaRosen, L. Immunity, 1998, 8(4), 451-460.

[117] Nagaraju, K.; Cox, A.; Casciola-Rosen, L.; Rosen, A. Arthritis Rheum., 2001, 44(10), 2376-2386.

[118] Schachna, L.; Wigley, F.M.; Morris, S.; Gelber, A.C.; Rosen, A.; CasciolaRosen, L. Arthritis Rheum., 2002, 46(7), 1873-1884.

[119] Rosen, A.; Casciola-Rosen, L.; Ahearn, J. J. Exp. Med., 1995, 181(4), 15571561 .

[120] Casciola-Rosen, L.; Rosen, A.; Petri, M.; Schlissel, M. Proc. Natl. Acad. Sci. USA, 1996, 93(4), 1624-1629.

[121] Stach, C.M.; Turnay, X.; Voll, R.E.; Kern, P.M.; Kolowos, W.; Beyer, T.D.; Kalden, J.R.; Herrmann, M. Cell Death Differ., 2000, 7(10), 911-915.

[122] Casiano, C.A.; Martin, S.J.; Green, D.R.; Tan, E.M. J. Exp. Med., 1996, 184(2), 765-770.

[123] Utz, P.J.; Hottelet, M.; Schur, P.H.; Anderson, P. J. Exp. Med., 1997, 185(5), 843-854.

[124] Casciola-Rosen, L.A.; Anhalt, G.; Rosen, A. J. Exp. Med., 1994, 179(4), 1317-1330.

[125] Lu, Q.; Lemke, G. Science, 2001, 293(5528), 306-311.

[126] Scott, R.S.; McMahon, E.J.; Pop, S.M.; Reap, E.A.; Caricchio, R.; Cohen, P.L.; Earp, H.S.; Matsushima, G.K. Nature, 2001, 411(6834), 207-211.

[127] Anderson, H.A.; Maylock, C.A.; Williams, J.A.; Paweletz, C.P.; Shu, H.; Shacter, E. Nat. Immunol., 2003, 4(1), 87-91.

[128] Arur, S.; Uche, U.E.; Rezaul, K.; Fong, M.; Scranton, V.; Cowan, A.E.; Mohler, W.; Han, D.K. Dev. Cell, 2003, 4(4), 587-598.

[129] Nakano, T.; Ishimoto, Y.; Kishino, J.; Umeda, M.; Inoue, K.; Nagata, K.; Ohashi, K.; Mizuno, K.; Arita, H. J. Biol. Chem., 1997, 272(47), 2941129414.

[130] Yoshida, H.; Kawane, K.; Koike, M.; Mori, Y.; Uchiyama, Y.; Nagata, S. Nature, 2005, 437(7059), 754-758.

[131] Nauta, A.J.; Trouw, L.A.; Daha, M.R.; Tijsma, O.; Nieuwland, R.; Schwaeble, W.J.; Gingras, A.R.; Mantovani, A.; Hack, E.C.; Roos, A. Eur. J. Immunol., 2002, 32(6), 1726-1736.

[132] Taylor, P.R.; Carugati, A.; Fadok, V.A.; Cook, H.T.; Andrews, M.; Carroll, M.C.; Savill, J.S.; Henson, P.M.; Botto, M.; Walport, M.J. J. Exp. Med., 2000, 192(3), 359-366.

[133] Gensler, T.J.; Hottelet, M.; Zhang, C.; Schlossman, S.; Anderson, P.; Utz, P.J. J. Autoimmun., 2001, 16(1), 59-69.
[134] Mevorach, D.; Zhou, J.L.; Song, X.; Elkon, K.B. J. Exp. Med., 1998, 188(2), 387-392.

[135] Hanayama, R.; Tanaka, M.; Miyasaka, K.; Aozasa, K.; Koike, M.; Uchiyama, Y.; Nagata, S. Science, 2004, 304(5674), 1147-1150.

[136] Cohen, P.L.; Caricchio, R.; Abraham, V.; Camenisch, T.D.; Jennette, J.C.; Roubey, R.A.; Earp, H.S.; Matsushima, G.; Reap, E.A. J. Exp. Med., 2002, 196(1), 135-140.

[137] Vyse, T.J.; Todd, J.A. Cell, 1996, 85(3), 311-318

[138] Mansson, L.; Torn, C.; Landin-Olsson, M. Int. J. Exp. Diabetes Res., 2001 2(2), 85-90.

[139] Kosugi, S.; Akamizu, T.; Takai, O.; Prabhakar, B.S.; Kohn, L.D. Thyroid, 1991, l(4), 321-330.

[140] Hauff, K.; Zamzow, C.; Law, W.J.; de Melo, J.; Kennedy, K.; Los, M. Arch. Immunol. Ther. Exp., 2005, 53(4), 308-320.

[141] Maddison, P.J. Adv. Exp. Med. Biol., 1999, 455, 141-145.

[142] Cruz, A.A.; Akaishi, P.M.; Vargas, M.A.; de Paula, S.A. Ophthal. Plast. Reconstr. Surg., 2007, 23(2), 104-108.

[143] Soy, M.; Guldiken, S.; Arikan, E.; Altun, B.U.; Tugrul, A. Rheumatol. Int. 2007, 27(6), 575-577.

[144] Hal Scofield, R.; Bruner, G.R.; Harley, J.B.; Namjou, B. Ann. Rheum. Dis., 2007, 66(3), 410-413.

[145] Zonana, M.F.; Reyes, E.; Weisman, A.K. J. Clin. Rheumatol., 2002, 8(6), 322-325.

[146] Kang, S.M.; Schneider, D.B.; Lin, Z.; Hanahan, D.; Dichek, D.A.; Stock P.G.; Baekkeskov, S. Nat. Med., 1997, 3(7), 738-743.

[147] Takeoka, Y.; Taguchi, N.; Shultz, L.; Boyd, R.L.; Naiki, M.; Ansari, A.A.; Gershwin, M.E. J. Autoimmun., 1999, 13(3), 325-334.

[148] O'Connor, L.; Strasser, A.; O'Reilly, L.A.; Hausmann, G.; Adams, J.M Cory, S.; Huang, D.C. EMBO J., 1998, 17(2), 384-395.

[149] Bouillet, P.; Metcalf, D.; Huang, D.C.; Tarlinton, D.M.; Kay, T.W.; Kontgen, F.; Adams, J.M.; Strasser, A. Science, 1999, 286(5445), 1735-1738.

[150] Kuroki, A.; Moll, T.; Lopez-Hoyos, M.; Fossati-Jimack, L.; Ibnou-Zekri, N.; Kikuchi, S.; Merino, J.; Merino, R.; Izui, S. Eur. J. Immunol., 2004, 34(4), 1077-1084.

[151] Strasser, A.; Whittingham, S.; Vaux, D.L.; Bath, M.L.; Adams, J.M.; Cory, S.; Harris, A.W. Proc. Natl. Acad. Sci. USA, 1991, 88(19), 8661-8665.

[152] Chen, M.; Huang, L.; Wang, J. Blood, 2007, 109(10), 4360-7.

[153] Xu, L.; Zhang, L.; Yi, Y.; Kang, H.K.; Datta, S.K. Nat. Med., 2004, 10(4), 411-415.

[154] Napirei, M.; Karsunky, H.; Zevnik, B.; Stephan, H.; Mannherz, H.G.; Moroy, T. Nat. Genet., 2000, 25(2), 177-181.

[155] Bitar, D.M.; Whitacre, C.C. Cell. Immunol., 1988, 112(2), 364-370.

[156] Levine, S.; Sowinski, R.; Kies, M.W. Proc. Soc. Exp. Biol. Med., 1972, 139(2), 506-510.

[157] Zhang, Z.J.; Davidson, L.; Eisenbarth, G.; Weiner, H.L. Proc. Natl. Acad. Sci. USA, 1991, 88(22), 10252-10256.

[158] Norman, P.S.; Nicodemus, C.F.; Creticos, P.S.; Wood, R.A.; Eggleston, P.A.; Lichtenstein, L.M.; Kagey-Sobotka, A.; Proud, D. Int. Arch. Allergy Immunol., 1997, 113(1-3), 224-226.

[159] Blanas, E.; Carbone, F.R.; Allison, J.; Miller, J.F.; Heath, W.R. Science, 1996, 274(5293), 1707-1709.

[160] Boers, M. Arthritis Rheum., 2001, 44(11), 2703-2704.

[161] da Silva, A.J.; Brickelmaier, M.; Majeau, G.R.; Li, Z.; Su, L.; Hsu, Y.M.; Hochman, P.S. J. Immunol., 2002, 168(9), 4462-4471.

[162] Mease, P.J. Skin. Therapy Lett., 2003, 8(1), 1-4.

[163] Rudick, R.A.; Goodkin, D.E.; Jacobs, L.D.; Cookfair, D.L.; Herndon, R.M.; Richert, J.R.; Salazar, A.M.; Fischer, J.S.; Granger, C.V.; Simon, J.H.; Alam, J.J.; Simonian, N.A.; Campion, M.K.; Bartoszak, D.M.; Bourdette, D.N.; Braiman, J.; Brownscheidle, C.M.; Coats, M.E.; Cohan, S.L.; Dougherty, D.S.; Kinkel, R.P.; Mass, M.K.; Munschauer, F.E.; Priore, R.L.; Whitham, R.H. Neurology, 1997, 49(2), 358-363.

[164] Simon, J.H.; Jacobs, L.D.; Campion, M.; Wende, K.; Simonian, N.; Cookfair, D.L.; Rudick, R.A.; Herndon, R.M.; Richert, J.R.; Salazar, A.M.; Alam, J.J.; Fischer, J.S.; Goodkin, D.E.; Granger, C.V.; Lajaunie, M.; MartensDavidson, A.L.; Meyer, M.; Sheeder, J.; Choi, K.; Scherzinger, A.L.; Bartoszak, D.M.; Bourdette, D.N.; Braiman, J.; Brownscheidle, C.M.; Whitham, R.H. Ann. Neurol., 1998, 43(1), 79-87.

[165] Schiemann, B.; Gommerman, J.L.; Vora, K.; Cachero, T.G.; ShulgaMorskaya, S.; Dobles, M.; Frew, E.; Scott, M.L. Science, 2001, 293(5537), 2111-2114.

[166] Schneider, P.; MacKay, F.; Steiner, V.; Hofmann, K.; Bodmer, J.L.; Holler, N.; Ambrose, C.; Lawton, P.; Bixler, S.; Acha-Orbea, H.; Valmori, D.; Romero, P.; Werner-Favre, C.; Zubler, R.H.; Browning, J.L.; Tschopp, J. J. Exp. Med., 1999, 189(11), 1747-1756.

[167] Thompson, J.S.; Schneider, P.; Kalled, S.L.; Wang, L.; Lefevre, E.A.; Cachero, T.G.; MacKay, F.; Bixler, S.A.; Zafari, M.; Liu, Z.Y.; Woodcock, S.A.; Qian, F.; Batten, M.; Madry, C.; Richard, Y.; Benjamin, C.D.; Browning, J.L.; Tsapis, A.; Tschopp, J.; Ambrose, C. J. Exp. Med., 2000, 192(1), 129 135.

[168] Zhang, J.; Roschke, V.; Baker, K.P.; Wang, Z.; Alarcon, G.S.; Fessler, B.J.; Bastian, H.; Kimberly, R.P.; Zhou, T. J. Immunol., 2001, 166(1), 6-10.

[169] Cheema, G.S.; Roschke, V.; Hilbert, D.M.; Stohl, W. Arthritis Rheum., 2001, 44(6), 1313-1319. 
[170] Groom, J.; Kalled, S.L.; Cutler, A.H.; Olson, C.; Woodcock, S.A.; Schneider, P.; Tschopp, J.; Cachero, T.G.; Batten, M.; Wheway, J.; Mauri, D.; Cavill, D.; Gordon, T.P.; Mackay, C.R.; Mackay, F. J. Clin. Invest., 2002, 109(1), 59-68.

[171] Khare, S.D.; Sarosi, I.; Xia, X.Z.; McCabe, S.; Miner, K.; Solovyev, I.; Hawkins, N.; Kelley, M.; Chang, D.; Van, G.; Ross, L.; Delaney, J.; Wang, L.; Lacey, D.; Boyle, W.J.; Hsu, H. Proc. Natl. Acad. Sci. USA, 2000, 97(7), 3370-3375.

[172] Szodoray, P.; Jellestad, S.; Teague, M.O.; Jonsson, R. Lab. Invest., 2003, 83(3), 357-365.

[173] Halpern, W.G.; Lappin, P.; Zanardi, T.; Cai, W.; Corcoran, M.; Zhong, J.; Baker, K.P. Toxicol. Sci., 2006, $91(2), 586-599$.

[174] Croft, M.; Swain, S.L. J. Immunol., 1991, 146(12), 4055-4064.

[175] Houssiau, F.A.; Devogelaer, J.P.; Van Damme, J.; de Deuxchaisnes, C.N.; Van Snick, J. Arthritis Rheum., 1988, 31(6), 784-788.

[176] Louis, E.; Belaiche, J.; van Kemseke, C.; Franchimont, D.; de Groote, D.; Gueenen, V.; Mary, J.Y. Eur. J. Gastroenterol. Hepatol., 1997, 9(10), 939944.

[177] Alonzi, T.; Fattori, E.; Lazzaro, D.; Costa, P.; Probert, L.; Kollias, G.; De Benedetti, F.; Poli, V.; Ciliberto, G. J. Exp. Med., 1998, 187(4), 461-468.

[178] Sasai, M.; Saeki, Y.; Ohshima, S.; Nishioka, K.; Mima, T.; Tanaka, T.; Katada, Y.; Yoshizaki, K.; Suemura, M.; Kishimoto, T. Arthritis Rheum., 1999, 42(8), 1635-1643.

[179] Maini, R.N.; Taylor, P.C.; Szechinski, J.; Pavelka, K.; Broll, J.; Balint, G.; Emery, P.; Raemen, F.; Petersen, J.; Smolen, J.; Thomson, D.; Kishimoto, T. Arthritis Rheum., 2006, 54(9), 2817-2829.

[180] Woo, P.; Wilkinson, N.; Prieur, A.M.; Southwood, T.; Leone, V.; Livermore, P.; Wythe, H.; Thomson, D.; Kishimoto, T. Arthritis Res. Ther., 2005, 7(6), R1281-1288.

[181] Mihara, M.; Kotoh, M.; Nishimoto, N.; Oda, Y.; Kumagai, E.; Takagi, N.; Tsunemi, K.; Ohsugi, Y.; Kishimoto, T.; Yoshizaki, K.; Takeda, Y. Clin. Immunol., 2001, 98(3), 319-326.

[182] Mihara, M.; Takagi, N.; Takeda, Y.; Ohsugi, Y. Clin. Exp. Immunol., 1998, 112(3), 397-402.

[183] Takagi, N.; Mihara, M.; Moriya, Y.; Nishimoto, N.; Yoshizaki, K.; Kishimoto, T.; Takeda, Y.; Ohsugi, Y. Arthritis Rheum., 1998, 41(12), 2117-2121.

[184] Brennan, D.C.; Yui, M.A.; Wuthrich, R.P.; Kelley, V.E. J. Immunol., 1989, 143(11), 3470-3475.

[185] Bresnihan, B. Clin. Exp. Rheumatol., 2002, 20 (5 Suppl 27), S32-34

[186] Jiang, Y.; Genant, H.K.; Watt, I.; Cobby, M.; Bresnihan, B.; Aitchison, R.; McCabe, D. Arthritis Rheum, 2000, 43(5), 1001-1009.

[187] Nuki, G.; Bresnihan, B.; Bear, M.B.; McCabe, D. Arthritis Rheum., 2002, 46(11), 2838-2846.

[188] Ostendorf, B.; Iking-Konert, C.; Kurz, K.; Jung, G.; Sander, O.; Schneider, M. Ann. Rheum. Dis., 2005, 64(4), 630-633.

[189] Bendele, A.; McAbee, T.; Sennello, G.; Frazier, J.; Chlipala, E.; McCabe, D. Arthritis Rheum., 1999, 42(3), 498-506.

[190] Wong, C.K.; Ho, C.Y.; Li, E.K.; Lam, C.W. Lupus, 2000, 9(8), 589-593.

[191] Cross, A.H.; Stark, J.L.; Lauber, J.; Ramsbottom, M.J.; Lyons, J.A. J. Neuroimmunol., 2006, 180(1-2), 63-70.

[192] Edwards, J.C.; Leandro, M.J.; Cambridge, G. Curr. Dir. Autoimmun., 2005, 8, 175-192.

[193] Giagounidis, A.A.; Anhuf, J.; Schneider, P.; Germing, U.; Sohngen, D.; Quabeck, K.; Aul, C. Eur. J. Haematol., 2002, 69(2), 95-100.

[194] Ng, K.P.; Leandro, M.J.; Edwards, J.C.; Ehrenstein, M.R.; Cambridge, G.; Isenberg, D.A. Ann. Rheum. Dis., 2006, 65(7), 942-945.

[195] Stashenko, P.; Nadler, L.M.; Hardy, R.; Schlossman, S.F. J. Immunol., 1980, 125(4), 1678-1685.

[196] Demidem, A.; Lam, T.; Alas, S.; Hariharan, K.; Hanna, N.; Bonavida, B. Cancer Biother. Radiopharm., 1997, 12(3), 177-186.

[197] Dorner, T.; Kaufmann, J.; Wegener, W.A.; Teoh, N.; Goldenberg, D.M.; Burmester, G.R. Arthritis Res. Ther., 2006, 8(3), R74.

[198] Steinfeld, S.D.; Tant, L.; Burmester, G.R.; Teoh, N.K.; Wegener, W.A.; Goldenberg, D.M.; Pradier, O. Arthritis Res. Ther., 2006, 8(4), R129. Ben-Nun, A.; Cohen, I.R. Eur. J. Immunol., 1981, 11(11), 949-952.

[200] Schluesener, H.J.; Wekerle, H. J. Immunol., 1985, 135(5), 3128-3133.

[201] Sloan-Lancaster, J.; Allen, P.M. Annu. Rev. Immunol., 1996, 14, 1-27.

[202] Ragazzo, J.L.; Ozaki, M.E.; Karlsson, L.; Peterson, P.A.; Webb, S.R. Proc. Natl. Acad. Sci. USA, 2001, 98(1), 241-246.

[203] Sloan-Lancaster, J.; Evavold, B.D.; Allen, P.M. Nature, 1993, 363(6425), 156-159.

[204] Steinman, L. J. Autoimmun., 2000, 14(4), 278-282.

[205] Neuhaus, O.; Farina, C.; Yassouridis, A.; Wiendl, H.; Then Bergh, F.; Dose, T.; Wekerle, H.; Hohlfeld, R. Proc. Natl. Acad. Sci. USA, 2000, 97(13), 7452-7457.

[206] Lafaille, J.J.; Keere, F.V.; Hsu, A.L.; Baron, J.L.; Haas, W.; Raine, C.S.; Tonegawa, S. J. Exp. Med., 1997, 186(2), 307-312.

[207] Pakala, S.V.; Kurrer, M.O.; Katz, J.D. J. Exp. Med., 1997, 186(2), 299-306.

[208] Finck, B.K.; Linsley, P.S.; Wofsy, D. Science, 1994, 265(5176), 1225-1227.

[209] Cross, A.H.; Girard, T.J.; Giacoletto, K.S.; Evans, R.J.; Keeling, R.M.; Lin, R.F.; Trotter, J.L.; Karr, R.W. J. Clin. Invest., 1995, 95(6), 2783-2789.

[210] Abrams, J.R.; Kelley, S.L.; Hayes, E.; Kikuchi, T.; Brown, M.J.; Kang, S.; Lebwohl, M.G.; Guzzo, C.A.; Jegasothy, B.V.; Linsley, P.S.; Krueger, J.G. J. Exp. Med., 2000, 192(5), 681-694.
[211] Kremer, J.M.; Westhovens, R.; Leon, M.; Di Giorgio, E.; Alten, R.; Steinfeld, S.; Russell, A.; Dougados, M.; Emery, P.; Nuamah, I.F.; Williams, G.R.; Becker, J.C.; Hagerty, D.T.; Moreland, L.W. N. Engl. J. Med., 2003, 349(20), 1907-1915.

[212] Kremer, J.M.; Dougados, M.; Emery, P.; Durez, P.; Sibilia, J.; Shergy, W.; Steinfeld, S.; Tindall, E.; Becker, J.C.; Li, T.; Nuamah, I.F.; Aranda, R.; Moreland, L.W. Arthritis Rheum., 2005, 52(8), 2263-2271.

[213] Westhovens, R.; Cole, J.C.; Li, T.; Martin, M.; Maclean, R.; Lin, P.; Blaisdell, B.; Wallenstein, G.V.; Aranda, R.; Sherrer, Y. Rheumatology (Oxford), 2006, 45(10), 1238-1246.

[214] Datta, S.K.; Kalled, S.L. Arthritis Rheum., 1997, 40(10), 1735-1745.

[215] Balasa, B.; Krahl, T.; Patstone, G.; Lee, J.; Tisch, R.; McDevitt, H.O.; Sarvetnick, N. J. Immunol., 1997, 159(9), 4620-4627.

[216] Durie, F.H.; Fava, R.A.; Foy, T.M.; Aruffo, A.; Ledbetter, J.A.; Noelle, R.J. Science, 1993, 261(5126), 1328-1330.

[217] Daikh, D.I.; Finck, B.K.; Linsley, P.S.; Hollenbaugh, D.; Wofsy, D. J. Immunol., 1997, 159(7), 3104-3108.

[218] Reynolds, J.; Khan, S.B.; Allen, A.R.; Benjamin, C.D.; Pusey, C.D. Kidney Int., 2004, 66(4), 1444-1452.

[219] t Hart, B.A.; Blezer, E.L.; Brok, H.P.; Boon, L.; de Boer, M.; Bauer, J.; Laman, J.D. J. Neuroimmunol., 2005, 16(1-2), 31-39.

[220] Davis, J.C. Jr.; Totoritis, M.C.; Rosenberg, J.; Sklenar, T.A.; Wofsy, D. J. Rheumatol., 2001, 28(1), 95-101.

[221] Kuwana, M.; Kawakami, Y.; Ikeda, Y. Blood, 2003, 101(2), 621-623.

[222] Kalunian, K.C.; Davis, J.C. Jr.; Merrill, J.T.; Totoritis, M.C.; Wofsy, D. Arthritis Rheum., 2002, 46(12), 3251-3258.

[223] Kawai, T.; Andrews, D.; Colvin, R.B.; Sachs, D.H.; Cosimi, A.B. Nat. Med., 2000, 6(2), 114.

[224] Ben-Nun, A.; Wekerle, H.; Cohen, I.R. Nature, 1981, 292(5818), 60-61.

[225] Ben-Nun, A.; Wekerle, H.; Cohen, I.R. Eur. J. Immunol., 1981, 11(3), 195199.

[226] Jiang, H.; Kashleva, H.; Xu, L.X.; Forman, J.; Flaherty, L.; Pernis, B.; Braunstein, N.S.; Chess, L. Proc. Natl. Acad. Sci. USA, 1998, 95(8), 4533 4537.

[227] Sun, D.; Qin, Y.; Chluba, J.; Epplen, J.T.; Wekerle, H. Nature, 1988 332(6167), 843-845.

[228] Howell, M.D.; Winters, S.T.; Olee, T.; Powell, H.C.; Carlo, D.J.; Brostoff, S.W. Science, 1989, 246(4930), 668-670.

[229] Vandenbark, A.A.; Hashim, G.; Offner, H. Nature, 1989, 341(6242), 541 544.

[230] Acha-Orbea, H.; Mitchell, D.J.; Timmermann, L.; Wraith, D.C.; Tausch, G.S.; Waldor, M.K.; Zamvil, S.S.; McDevitt, H.O.; Steinman, L. Cell, 1988 54(2), 263-273.

[231] Urban, J.L.; Kumar, V.; Kono, D.H.; Gomez, C.; Horvath, S.J.; Clayton, J.; Ando, D.G.; Sercarz, E.E.; Hood, L. Cell, 1988, 54(4), 577-592.

[232] Vandenbark, A.A.; Hashim, G.A.; Offner, H. J. Neurosci. Res., 1996, 43(4), 391-402.

[233] Achiron, A.; Lavie, G.; Kishner, I.; Stern, Y.; Sarova-Pinhas, I.; Ben-Aharon, T.; Barak, Y.; Raz, H.; Lavie, M.; Barliya, T.; Faibel, M.; Cohen, I.R.; Mandel, M. Clin. Immunol., 2004, 113(2), 155-160.

[234] Zang, Y.C.; Hong, J.; Rivera, V.M.; Killian, J.; Zhang, J.Z. J. Immunol., 2000, 164(8), 4011-4017.

[235] Zhang, J.Z.; Rivera, V.M.; Tejada-Simon, M.V.; Yang, D.; Hong, J.; Li, S.; Haykal, H.; Killian, J.; Zang, Y.C. J. Neurol., 2002, 249(2), 212-218.

[236] Bourdette, D.N.; Whitham, R.H.; Chou, Y.K.; Morrison, W.J.; Atherton, J.; Kenny, C.; Liefeld, D.; Hashim, G.A.; Offner, H.; Vandenbark, A.A. J. Im munol., 1994, 152(5), 2510-2519.

[237] Chou, Y.K.; Morrison, W.J.; Weinberg, A.D.; Dedrick, R.; Whitham, R.; Bourdette, D.N.; Hashim, G.; Offner, H.; Vandenbark, A.A. J. Immunol., 1994, 152(5), 2520-2529.

[238] Alexander, H.C.; Booy, E.P.; Xiao, W.; Baust, H.; Ezzati, P.; Los, M. Arch Immunol. Ther. Exp., 2007, 55, 139-149.

[239] Takiguchi, M.; Murakami, M.; Nakagawa, I.; Saito, I.; Hashimoto, A.; Uede, T. Life Sci., 2000, 66(11), 991-1001.

[240] Kawaguchi, Y. Hokkaido Igaku Zasshi, 1999, 74(6), 467-475.

[241] Ijima, K.; Murakami, M.; Okamoto, H.; Inobe, M.; Chikuma, S.; Saito, I Kanegae, Y.; Kawaguchi, Y.; Kitabatake, A.; Uede, T. Hum. Gene Ther. 2001, 12(9), 1063-1077.

[242] Cottard, V.; Mulleman, D.; Bouille, P.; Mezzina, M.; Boissier, M.C.; Bessis, N. Gene Ther., 2000, 7(22), 1930-1939.

[243] Ho, S.H.; Lee, H.J.; Kim, D.S.; Jeong, J.G.; Kim, S.; Yu, S.S.; Jin, Z.; Kim, S.; Kim, J.M. Biochem. Biophys. Res. Commun., 2006, 343(3), 816-824.

[244] Martino, G.; Poliani, P.L.; Furlan, R.; Marconi, P.; Glorioso, J.C.; Adorini, L.; Comi, G. J. Neuroimmunol., 2000, 107(2), 184-190.

[245] Piccirillo, C.A.; Chang, Y.; Prud'homme, G.J. J. Immunol., 1998, 161(8), 3950-3956.

[246] Poliani, P.L.; Brok, H.; Furlan, R.; Ruffini, F.; Bergami, A.; Desina, G; Marconi, P.C.; Rovaris, M.; Uccelli, A.; Glorioso, J.C.; Penna, G.; Adorini, L.; Comi, G.; t Hart, B.; Martino, G. Hum. Gene Ther., 2001, 12(8), 905-920.

[247] Zhang, Z.L.; Lin, B.; Yu, L.Y.; Shen, S.X.; Zhu, L.H.; Wang, W.P.; Guo, L.H. Acta Pharmacol. Sin., 2003, 24(9), 885-890.

[248] Kim, J.M.; Ho, S.H.; Hahn, W.; Jeong, J.G.; Park, E.J.; Lee, H.J.; Yu, S.S.; Lee, C.S.; Lee, Y.W.; Kim, S. Gene Ther., 2003, 10(15), 1216-1224.

[249] Kim, J.M.; Jeong, J.G.; Ho, S.H.; Hahn, W.; Park, E.J.; Kim, S.; Yu, S.S.; Lee, Y.W.; Kim, S. Gene Ther, 2003, 10(18), 1543-1550. 
[250] Lawson, B.R.; Prud'homme, G.J.; Chang, Y.; Gardner, H.A.; Kuan, J.; Kono, D.H.; Theofilopoulos, A.N. J. Clin. Invest., 2000, 106(2), 207-215.

[251] Prud'homme, G.J.; Chang, Y. Gene Ther., 1999, 6(5), 771-777.

[252] Kim, S.H.; Lechman, E.R.; Kim, S.; Nash, J.; Oligino, T.J.; Robbins, P.D Mol. Ther., 2002, 6(5), 591-600.

[253] Misaki, Y.; Setoguchi, K.; Araki, Y.; Fujio, K.; Kawahata, K.; Kitamura, T.; Yamamoto, K. Nihon Rinsho Meneki Gakkai Kaishi, 2000, 23(6), 538-541.

[254] Zhang, H.; Yang, Y.; Horton, J.L.; Samoilova, E.B.; Judge, T.A.; Turka, L.A.; Wilson, J.M.; Chen, Y. J. Clin. Invest., 1997, 100(8), 1951-1957.

[255] Yao, Q.; Glorioso, J.C.; Evans, C.H.; Robbins, P.D.; Kovesdi, I.; Oligino, T.J.; Ghivizzani, S.C. J. Gene Med., 2000, 2(3), 210-219.

Received: July 01, 2007

Revised: September 17, 2007

Accepted: September 17, 2007
$[256]$ munol., 1999, 162(1), 603-608.

[258] Rabinovitch, A.; Suarez-Pinzon, W.; Strynadka, K.; Ju, Q.; Edelstein, D.; Brownlee, M.; Korbutt, G.S.; Rajotte, R.V. Diabetes, 1999, 48(6), 1223 1229.

[259] Anderson, J.E.; Hansen, L.L.; Mooren, F.C.; Post, M.; Hug, H.; Zuse, A.; Los, M. Drug Resist. Updat., 2006, 9(4-5), 198-210.

[260] Kroczak, T.J.; Baran, J.; Pryjma, J.; Siedlar, M.; Rashedi, I.; Hernandez, E.; Alberti, E.M. S.; Los, M. Expert Opin. Ther. Targets, 2006, 10, 289-302. 